\title{
Volcanic complexes in the eastern ridge of the Canary Islands: the Miocene activity of the island of Fuerteventura
}

\author{
E. Ancochea ${ }^{\mathrm{a}, *}$, J.L. Brändle ${ }^{\text {a }}$, C.R. Cubas ${ }^{\mathrm{b}}$, F. Hernán ${ }^{\mathrm{b}}$, M.J. Huertas ${ }^{\mathrm{a}}$ \\ ${ }^{a}$ Dpto. Petrología y Geoquímica, Universidad Complutense, Inst. Geología Económica, C.S.I.C. Fac. C. Geológicas, 28040 Madrid, Spain \\ ${ }^{b}$ Dpto. Edafología y Geología, Universidad de La Laguna, 38206 Tenerife, Spain
}

Received 20 October 1994; accepted 11 July 1995

\begin{abstract}
Fuerteventura has been since early stages of its growth the result of three different adjacent large volcanic complexes: Southern, Central and Northern. The definition of these volcanic complexes and their respective growing episodes is based on volcano-stratigraphic, morphological and structural criteria, particularly radial dyke swarms. Each complex has its own prolonged history that might be longer than $10 \mathrm{~m} . y$. During that time, several periods of activity alternating with gaps accompanied by important erosion took place. The evolution of each volcanic complex has been partially independent but all the three are affected by at least three Miocene tectonic phases that controlled considerably their activity. The volcanic complexes are deeply eroded and partially submerged. In the core of the Northem and the Central volcanic complexes there is a set of submarine and plutonic rocks intensely traversed by a dyke swarm, known as the Basal Complex. The Basal Complex has been interpreted in different ways but all previous authors have considered it to be prior to the subaerial shield stage of the island. Here we advance the idea that the Basal Complex represent the submarine growing stage of the volcanic complexes and the hypabyssal roots (plutons and dykes) of their successive subaerial growing episodes.

Two seamounts situated nearby, southwest of the island, might be interpreted as remains of two other major volcanoes. These two volcanoes, together with those forming the present emerged island of Fuerteventura, and finally those of Famara and Los Ajaches situated further north on Lanzarote constitute a chain of volcanoes located along a lineation which is subparallel to the northwestern African coastlinc and which may relatc to carly Atlantic spreading trends in the area.
\end{abstract}

\section{Introduction}

Fuerteventura, the easternmost of the Canary Islands and nearest to the neighbouring African continent, is exceptional among oceanic islands, due, firstly, to its location on a passive continental margin

\footnotetext{
* Corresnonding author
}

characterized by the absence of significant magmatism, secondly, to the unusually long time span of the volcanic activity (at least $35 \mathrm{~m}$.y., but possibly more than 50 m.y.), thirdly, to the presence of submarine sediments and volcanics, and plutonic rocks, and, lastly, to the existence of carbonatites.

Together with Lanzarote, Fuerteventura represents the emergent crest of the Eastern Canarian Volcanic Ridge that extends north-northeast below sea level (Dañoheitia. 1988: Dañoheitia and Collette 1989) 


\section{E. Ancochea et al.}

and runs roughly parallel to the African coast (100 $\mathrm{km}$ from Fuerteventura, Fig. 1) and to the ocean-floor spreading trend. In this paper we develop a model according to which Fuerteventura is built up of several independent emergent volcanoes together with other submarine ones to the south.

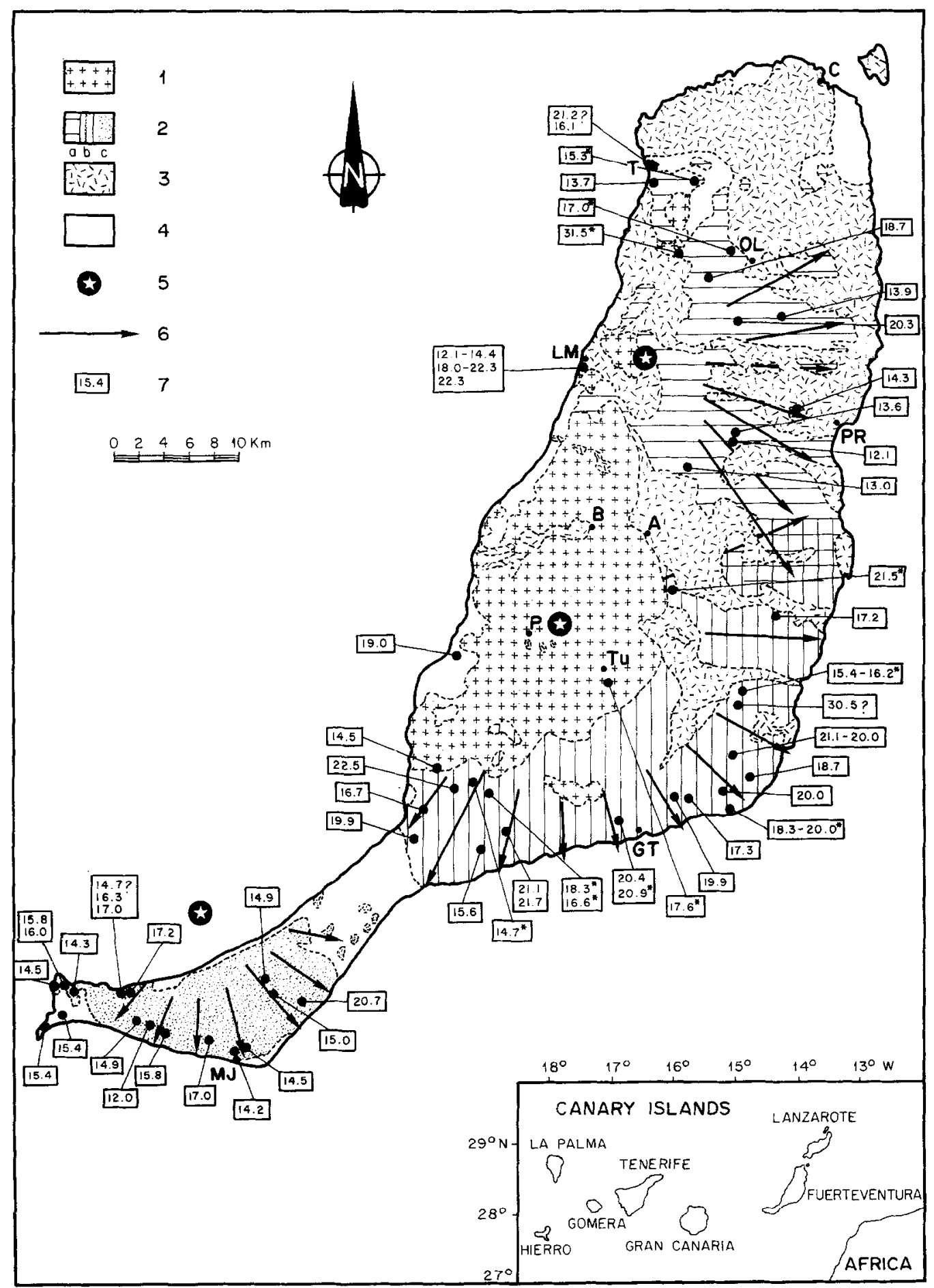




\section{Geological setting}

Two major structural and petrological stages have been traditionally distinguished on Fuerteventura: the Basal Complex and the Subaerial Volcanic Series of Neogene and Quaternary ages. The Basal Complex (BC; Bravo, 1964; Fúster and Aguilar, 1965; Fúster et al., 1968a; Stillman et al., 1975) is a thick Late Cretaceous sedimentary sequence overlain by submarine volcanics and intruded by an intense NNESSW-trending sheeted dyke swarm which formed in association with the emplacement of alkaline plutons. The $\mathrm{BC}$ has been interpreted in different ways, for example, as a normal oceanic crust fragment similar to some ophiolite complex such as the Troodos Massif in Cyprus (Gastesi, 1973), as part of a common substratum for all the Canary Islands (Cendrero, 1970), or as the subvolcanic roots of previous edifices (Hernández-Pacheco, 1973). In any case, all authors considered the entire $\mathrm{BC}$ as the earlier substratum for Fuerteventura, reflecting a growth stage dating back to before the subaerial shield stage (Fúster et al., 1980; Le Bas et al., 1986; Stillman, 1987; Muñoz and Sagredo, 1989; Cantagrel et al., 1993). However, as we shall endeavour to show in this work, this interpretation should be modified.

Within the Subaerial Volcanic Series, several episodes are recognised. The earliest and most important is the Old Basalts Series (OBS), equivalent to the Basaltic Table land Formation of Hausen (1958), or Series I of Fúster et al. (1968a). Previous authors considered it to be heterogeneous with local unconformities, although continuous, mainly horizontal or slightly tilted, and unconformably overlying the $\mathrm{BC}$. At a later date, after a period lasting about $7 \mathrm{~m} . \mathrm{y}$. (Coello et al., 1992) and characterized by lack of activity and erosion, new basaltic materials were erupted giving rise to the Recent Series. This, series less important in terms of volume, although it contin-
Table 1

Volcano-stratigraphic sketch of the Old Basaltic Series of Fuerteventura and age ranks according to radiometric age data available

\begin{tabular}{lc}
\hline Units & Age (Ma) \\
\hline Northern Volcanic Complex (NVC) & \\
Northern Volcanic Complex II & $14.3-12.8$ \\
Ampuyenta Formation & $(15.3-14.3)$ \\
Northem Volcanic Complex I & \\
$\quad$ Upper NVC-I & $17.0-15.3$ \\
$\quad$ Middle NVC-I & $22 ?$ \\
$\quad$ Lower NVC-I & $?$ \\
Central Volcunic Complex (CVC) & \\
Los Tableros Formation & 13.2 \\
Central Volcanic Complex III, & $17.5-14.5$ \\
$\quad$ Melindraga and Tamacite formations & \\
Central Volcanic Complex II & $22.5-20.0$ \\
Central Volcanic Complex I & $>22.5$ \\
Southern Volcanic Complex (SVC) & \\
Southem Volcanic Complex III & $15.2-14.2$ \\
Southem Volcanic Complex II & $17.2-15.4$ \\
Southern Volcanic Complex I & $20.7-19.3$ \\
\hline
\end{tabular}

ued until recent times, consists mainly of scattered pyroclastic cones and associated lava flows.

\section{Volcanic complexes in the Old Basaltic series}

In contrast to the models mentioned above, Ancochea et al. (1991), Cubas et al. (1992) and Hernán et al. (1993) had proposed that the OBS corresponds to three major volcanoes: the Central, Northern and Southern (Fig. 1). As shown further on, these three major volcanoes should be regarded as volcanic complexes since they built up during very long periods of activity (10 m.y.) and they are the result of different successive and overlapping volcanic constructs separated by gaps in activity which indicate the existence of independent magmatic cycles. Regional tectonic phases of activity are also recorded within each volcanic complex.

Fig. 1. Geological sketch of Fuerteventura. $l=$ Basal Complex; $2=$ Old Basaltic Series, $a=$ Northem Volcanic Complex, $b=$ Central Volcanic Complex, $c=$ Southern Volcanic Complex; $3=$ Recent Series; $4=$ sediments; $5=$ center of volcanic complex; $6=$ strike of

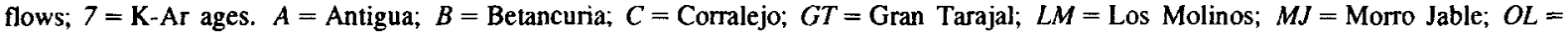
Oliva; $P=$ Pájara; $P R=$ Puerto del Rosario; $T=$ Tostón Cotillo; $T u=$ Tuineje. 


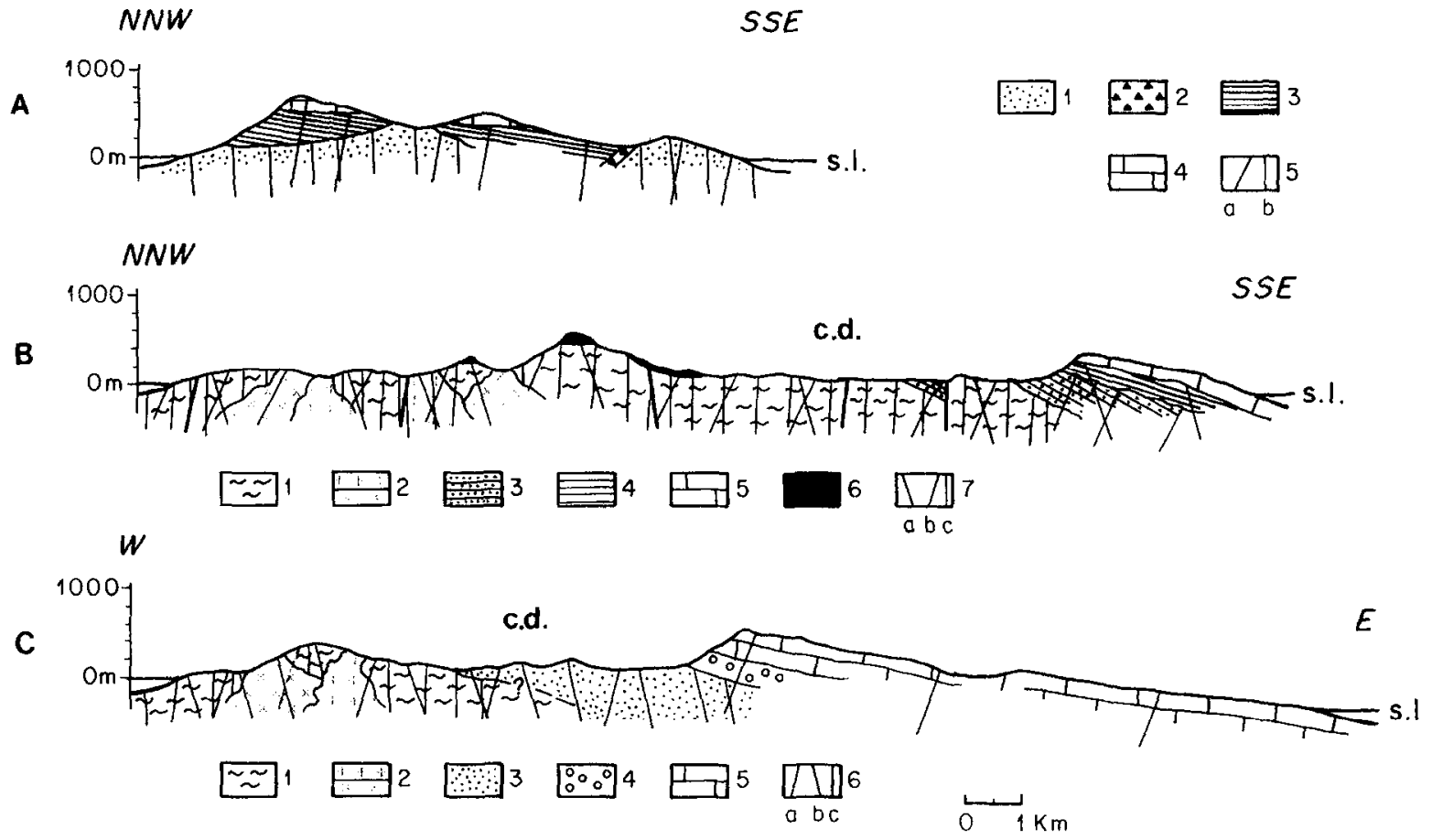

Fig. 2. Simplified general geological sketches of the volcanic complexes. (A) Southem Volcanic Complex: $1=$ SVC-I; $2=$ breccias; $3=$ SVC-II; $4=$ SVC-III; $5=$ dykes, $a=$ SVC-II and SVC-III, $b=$ SVC-I. (B) Central Volcanic Complex: $I=$ submarine materials; $2=$ plutonic rocks; $3=$ CVC-I; $4=$ CVC-II; $5=\mathrm{CVC}-\mathrm{III} ; 6=$ Melindraga Formation; $7=$ dykes, $a=\mathrm{CVC}$-II, $b=\mathrm{CVC}-\mathrm{I}, c=\mathrm{Basal}$ Complex; c.d. $=$ Central Depression. (C) Northem Volcanic Complex: $l=$ submarine materials; $2=$ plutonic rocks; $3=\mathrm{NVC}-\mathrm{I} ; 4=$ Ampuyenta Formation; $5=$ NVC.-II; $6=$ dykes, $a=$ NVC-II, $b=$ NVC-I, $c=$ Basal Complex; $c . d .=$ Central Depression; s.l. $=$ sea level.

Volcano-stratigraphic criteria have proved useful to define and to localize unconformities and hiatuses. Structural and morphological criteria, particularly dyke swarms, have been the key to separating all three major volcanoes and their succesive constructs. Lastly, the reinterpretation of available radiometric age data and new determinations have led to the development of a temporal framework for the whole Miocene subaerial evolution of Fuerteventura. The volcano-stratigraphical sketch is shown in Table 1 and Fig. 2.

\subsection{The Southern Volcanic Complex}

The Southern Volcanic Complex (SVC) on the so-called "Jandía peninsula" is separated from the Central Volcanic Complex (CVC) by "El Jable" a narrow, low ( $<200 \mathrm{~m}$ high) and plain sector covered by eolian sands and calcrete. The northern side shows a high $(800 \mathrm{~m})$ open-northwards semicircular escarpment "La Pared", from which a series of radial ravines alternating with "cuchillos" excavate southwards the OBS (Fig. 3). "Cuchillo" is a local morphological term used to denote relatively high,

Fig. 3. Southern Volcanic Complex. (A) Morphological sketch and reconstruction. (B) Dykes in the SVC-II and SVC-III. (C) Dykes in the SVC-I. In (B) and (C) unidirectional rose diagrams for dykes in each sector. Circles indicating percentage of dykes. 1,2 and $3=$ points situated at 200,400 and $600 \mathrm{~m}$ altitude, along cuchillos (see text); $4=$ morphological center, $5=$ cuchillos; $6=$ escarpment of "La Pared"; $7=$ palaeo-contours of the volcano; in (B) $8=$ dykes cutting the SVC-II and SVC-III, in (C) $8=$ dykes in the SVC-I; $9=$ dykes intruding in the SVC-I, but belonging to the SVC-1I or SVC-III; $10=$ converging area estimated for dykes in SVC-II and SVC-III; $11=$ idem in the SVC-I. $M J=$ Morro Jable. 


\section{E. Ancochea et al.}
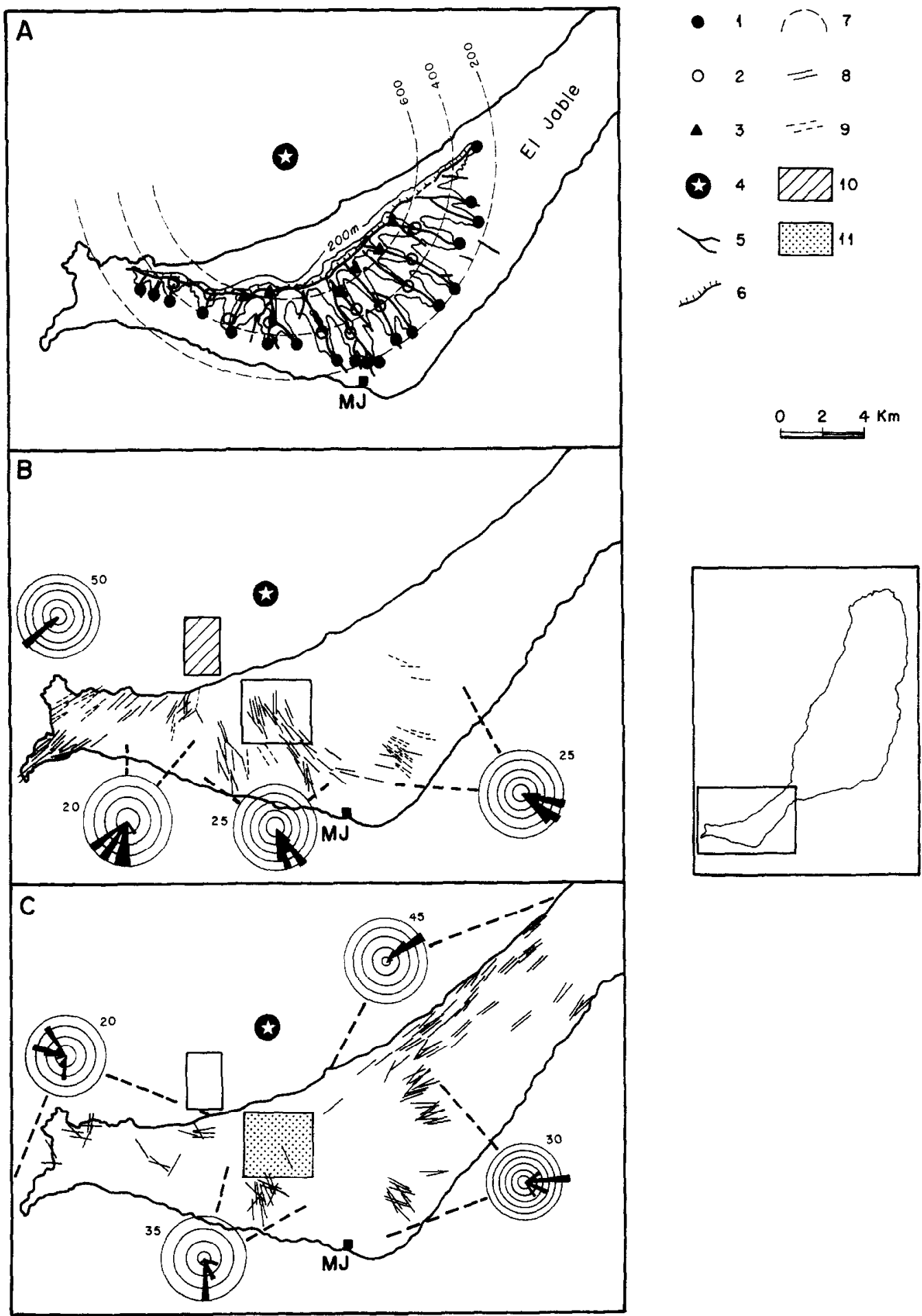
long and sharp crests separating ravines, which are frequent in Fuerteventura.

The Jandía peninsula is formed exclusively by OBS materials from three successive constructive episodes, namely, I, II and III, that built up the SVC (Table 1; Fig. 2A).

The Southern Volcanic Complex I (SVC-I) materials are exposed mainly along the northern coast at the base of the escarpment, in erosion "windows" at the bottom of some of the ravines, as isolated paleoravines up to $400 \mathrm{~m}$ high and under the sands of " $\mathrm{El}$ Jable'". These materials are frequently fractured, suggesting that faulting might account for the outcrops on different separated areas. Basalts are the most representative rocks (Table 2). Hydromagmatic pyroclasts were abundant at the early stages when the edifice emerged, although pahoehoe basaltic lava flows (typically ankaramitic) were subsequently erupted on top. They generally have normative $\mathrm{Ol}+$ Hy (recalculated in accordance with Le Maitre, 1976) but no $\mathrm{Ca}$-poor pyroxene, and they fall within the alkali field of Macdonald and Katsura (1964).

Felsic rocks are scarce (Muñoz, 1969; Cubas et al., 1988). They correspond to quartz-trachytes existing in the north as plugs, probably associated with felsic tuffs representing the uppermost stratigraphic level. These tuffs rest unconformably on the underlying basalts whose dykes are cut at the unconformity, which indicates that this last felsic episode took place after a significant erosion period. Taken together, the basalts and quartz-trachytes form a mildly alkaline series with no intermediate members.

The materials forming the Southern Volcanic Complex II (SVC-II) lie unconformably on the SVCI, filling a paleo-relief. Their total thickness, structure and distribution is therefore irregular. Basalt flows are subhorizontal or dip southwards and are locally intercalated with thick breccias derived from erosion of the SVC-I. About $90 \%$ of these rocks are basaltic in composition and trachybasaltic to a lesser degree, all of mildly alkaline affinity (Table 2). In some parts, particularly in the north along "la Pared", two different sequences can be distinguished. The lower sequence overlies a steep palaeo-slope inclined northwards and the horizontal position of flows indicates that a depression was filled up. At a later date the flows of the upper sequence poured out radially, as can be deduced from their radial dip, and advanced southwards, stacking up against higher relief situated further

Table 2

Approximate distribution of main petrographic types and their geochemical character in the different volcanic complexes

\begin{tabular}{|c|c|c|c|c|c|c|c|c|c|}
\hline \multirow{2}{*}{$\begin{array}{l}\text { Volcanic } \\
\text { complexes }\end{array}$} & \multirow{2}{*}{$\begin{array}{l}\text { Geochemical } \\
\text { character }\end{array}$} & \multicolumn{4}{|c|}{ Distribution of basaltic types (\%) } & \multirow[t]{2}{*}{$\% \mathbf{B}$} & \multirow[t]{2}{*}{$\% \mathrm{~TB}$} & \multirow{2}{*}{$\begin{array}{l}\% \text { BAT }+ \\
\text { TA }\end{array}$} & \multirow[t]{2}{*}{$\% \mathrm{~T}$} \\
\hline & & $O l P x-B$ & Oc.-Pic.B & $A n k \cdot-A n k B$ & $P l-B$ & & & & \\
\hline \multicolumn{10}{|l|}{ Southern } \\
\hline I & mildly alkaline & 39 & 11 & 50 & - & 100.0 & - & - & Yes \\
\hline II & mildly alkaline & 80 & 10 & - & 10 & 90.9 & 10.1 & - & - \\
\hline III & middle alkaline & 33 & 25 & 42 & - & 80.3 & 19.7 & - & Yes \\
\hline Angostura $\mathrm{F}$. & ultra-alkaline & 100 & - & - & - & 100.0 & - & - & - \\
\hline \multicolumn{10}{|l|}{ Central } \\
\hline I & mildly alkaline & 77 & - & 23 & - & 92.9 & - & 7.1 & - \\
\hline II & middle alkaline & 50 & 27 & 19 & 4 & 86.7 & 10.0 & 3.3 & Yes \\
\hline III & middle alkaline & 36 & 9 & 45 & 10 & 64.7 & 35.3 & - & - \\
\hline $\begin{array}{l}\text { Mclindraga, Tamacite } \\
\text { and Tableros Formations }\end{array}$ & high alkaline ultra-alkaline & 100 & - & - & & 72.8 & 27.2 & - & - \\
\hline \multicolumn{10}{|l|}{ Northern } \\
\hline I & $\begin{array}{l}\text { middle alkaline- } \\
\text { mildly alkaline }\end{array}$ & 40 & 30 & - & 30 & 71.5 & 21.4 & 7.1 & Yes \\
\hline II & alkaline & 48 & - & - & 52 & 62.7 & 19.6 & 17.7 & - \\
\hline Average & & & & & & 80.3 & 15.8 & 3.9 & - \\
\hline
\end{tabular}

$\mathrm{B}=$ basalts; $\mathrm{TB}=$ trachybasalts; $\mathrm{BAT}=$ basaltic trachyandesites; $\mathrm{TA}=$ trachyandesites; $\mathrm{T}=$ trachytes. Petrographic basaltic types in italics. $\mathrm{OIPx}-\mathrm{B}=$ olivine pyroxene and aphyric basalts; $\mathrm{Oc}-\mathrm{PicB}=\alpha$ ceanites and picritic basalts; Ank-AnkB = ankaramites and ankaramitic basalts; Pl-B = plagioclase basalts. 


\section{E. Ancochea et al.}

south. All this would appear to indicate that the source area for the SVC-II was located north of $\mathrm{La}$ Pared.

The Southern Volcanic Complex III (SVC-III) lies unconformably over the two earlier ones. The area where it crops out coincides largely with that of the SCV-II, although it extends further east and less to the west. Its materials constitute most of the northern Jandía scarp and the highest section of "cuchillos". The unconformity between both is minor and would not appear to represent, concerning the style of volcanism, a substantial change in the evolution of the SVC. The SVC-III controls, therefore, the main morphological features of the Jandía peninsula; it is more than $350 \mathrm{~m}$ thick and consists of ankaramites, olivine-pyroxene basalts and, to a lesser extent (20\%), trachybasalt flows (Table 2). A volcanic plug and its associated dykes (Muñoz, 1969; Cubas et al., 1988) are the only signs of late felsic activity. These rocks are Ne-normative undersaturated and meta-aluminous trachytes of mildly alkaline character.

The western tip of the Jandía peninsula differs from the rest in both geological and compositional terms. It consists of basalts and olivine nephelinites cut by a small number of dykes, which would indicate that it is more recent in age.

The radial, semicircular distribution of ravines and "cuchillos", together with the radial dip of material belonging to these three successives constructs (although particularly to the SVC-III), supports the existence of a large central volcano, the center of which would lie to the north of the Peninsula. The radial drainage pattern and the height of the interfluves should reflect the profile of this early volcanic cone. For each zone and for the same contour line, the most distant point from the theoretical center will be at the closest height to the primitive surface. Interpolated palaeocontours now at 200 , 400 and $600 \mathrm{~m}$, derived for this cone, are shown in Fig. 3A. The geometrical center of this cone, marking the likely site of the main emission center, is situated offshore north of the Peninsula.

\subsubsection{Dyke systems}

Dykes which are generally basaltic in composition are frequent in Jandía. Fúster et al. (1968a) and Feraud et al. (1985) noted that dyke strikes were variable but they considered them as a whole, regardless of the unit they traversed. Dykes are abundant in the SVC-I sometimes accounting for $10 \%$ of the whole rock and belonging to more than one swarm. The dykes cutting the SVC-II and III follow similar patterns. Most intrude into the SVC-II and only a few into the SVC-III. For this reason, given that the last one extends further east, there are fewer dykes in this area (Fig. 3B). The trend, although incomplete, is radial from $\mathrm{N} 130$ to $\mathrm{N} 240^{\circ}$ clockwise.

Some of the dykes cutting through the SVC-I belong necessarily to the swarm just examined (Fig. $3 B$ ), although another group of dykes intrudes into the SVC-I only (Fig. 3C). These older dykes run parallel to the coastline in the northeast (N50-N60 ) and towards the CVC where this strike is also found. In the northwest, and at isolated points where the SVC-I is exposed, the direction of dykes shows greater complexity. In any case, most of the dykes converge in a central zone on the Jandía peninsula (Fig. 3C) at the highest points. This complexity may be due to the existence of more than one swarm of dykes in the SVC-I related to more than one constructive phase.

\subsubsection{Age}

A wealth of radiometric age data exists for Fuerteventura (Fig. 1; Rona and Nalwalk, 1970; Abdel Monem et al., 1971; Grunau et al., 1975; Feraud, 1981; Feraud et al., 1985; Le Bas et al., 1986; Coello et al., 1992; Cantagrel et al., 1993; Balcells et al., 1994). Most of the data corresponding to the OBS have been published by Coello et al. (1992) and Balcells et al. (1994). Feraud et al. (1985) obtained age data only from dykes cutting the SVC and the CVC. However, the majority of the published ages were analyzed considering the OBS as a whole. The previous age data are summarized in Fig. 1.

The oldest age known (20.7 Ma) in the SVC corresponds to a dyke (Feraud, 1981; Feraud et al., 1985) which, according to its strike, could belong to the SVC-I and would thus give an approximate age for the early stage of this volcano. The scarcity of lava flows and the intense weathering thereof prevent more valid data from being obtained.

The ages for the SVC-II in its lower sequence are quite consistent, 17.0 and 16.3 Ma [Abdel Monem et 
al. (1971), recalculated in accordance with Steiger and Jaeger (1977)] and 17.2 and $16.9 \mathrm{Ma}$ (Balcells et al., 1994). Another group of age data, 15.8 and 15.4 $\mathrm{Ma}$ of Coello et al. (1992), 15.8 and $16.0 \mathrm{Ma}$ of Balcells et al. (1994) and a dyke dated to $15.9 \mathrm{Ma}$ by Feraud et al. (1985), can be attributed to the upper sequence.

As regards the uppermost part of the SVC-III, Coello et al. (1992) date basaltic flows to 15.0 and $14.9 \mathrm{Ma}$ and a trachyte to $15.2 \mathrm{Ma}$. Feraud et al. (1985) give ages of $14.9,14.5$ and $14.9 \mathrm{Ma}$ for dykes that could be interpreted as intruding into the SVCIII. Finally, another dyke dated by Feraud et al. (1985) at $12 \mathrm{Ma}$ would indicate a certain persistence of activity until that time.

In DSDP site 397 (Fig. 7), Schmincke and Von Rad (1979) have reported several volcanic and volcanoclastic levels, a glassy ash (A23) and four debris-flow deposits $\left(\mathrm{V}_{4}-\mathrm{V}_{1}\right)$. On the basis of stratigraphic criteria and available age data, these authors attributed an age of $19.3 \mathrm{Ma}$ to the earliest deposit A23 and interpreted it as a trachytic ashfall from Fuerteventura or Lanzarote. This age would coincide with that inferred for the trachytic tuffs found between the SVC-I and the SVC-II, i.e., an age which must lie somewhere between $20.7 \mathrm{Ma}$ (dyke in the SVC-I, dated by Feraud, 1981) and 17 Ma (age of the earlier flows in the SVC-II).

\subsection{The Central Volcanic Complex}

The Central Volcanic Complex (CVC) extends from Antigua, where it overlaps the NVC, to the "El Jable" which separates it from the SVC (Fig. 1). Three concentric semicircular areas are distinguished in this sector. The innermost and highest area, $400 \mathrm{~m}$ near the coast and $600-700 \mathrm{~m}$ inland, is formed exclusively by the Basal Complex. It is surrounded by the Central Depression, a flat plain where heights do not exceed $100-200 \mathrm{~m}$. BC and OBS rocks crop out here covered by thick successions of sediments, calcrete, colluvium deposits and subhistorical volcanoes which partially fill the depression. On the outermost area, only OBS materials are exposed. As in the SVC, successions of basaltic lava flows form "cuchillos" separated by radial ravines extending down to the coast (Fig. 4). In contrast with the observations in the SVC, many of the "cuchillos" do not merge at the headwaters zone but carry on up to the Central Depression. The innermost and outermost areas merge to the west where the depression disappears.

Three main constructive episodes separated by unconformities have been distinguished (Ancochea et al., 1991) in the CVC: I, II and III (Table 1; Fig. 2B).

The Central Volcanic Complex I (CVC-I) is exposed on the Central Depression, on the inner front flank of the "cuchillos" and along the ravines in between. Contact with the $\mathrm{BC}$ is frequently tectonic, though sometimes there is a continuous sequence without evidence of a break, but differences in the degree of weathering and in the intensity of dyking are always observed. It consists of a thick sequence, more than $1000 \mathrm{~m}$, of lava flows cut by dykes. The flows are essentially basaltic, mainly ankaramitic and of mildly alkaline affinity (Table 2 ).

The more poorly defined Central Volcanic Complex II (CVC-II) forms the top of the "cuchillos" or sometimes the "cuchillos" in their entirety. For the most part, it rests not on the $\mathrm{BC}$ but unconformably on the CVC-I. Both have similar dip and strike but the dip angle is smaller in the CVC-II $\left(10-20^{\circ}\right)$ than in the lower one $\left(20-30^{\circ}\right.$ or even $\left.40-45^{\circ}\right)$. In the western sector, they are separated by a $60-80 \mathrm{~m}$ thick polygenetic breccia composed of a clay-sandy matrix and heterogeneous basaltic fragments, possibly a debris flow derived from the CVC-I. The CVC-II consists of $300-500 \mathrm{~m}$ of scorias and thin lava flows and local interlayered pyroclastics, remains of small eruptive centers. Most flows are basaltic, with a lower proportion of differentiates

Fig. 4. Central Volcanic Complex. (A) Morphological sketch and reconstruction. (B) Dykes related to the southern focus. (C) Dykes related to the northern focus. In (B) and (C) unidirectional rose diagrams for dykes in each sector. 1,2 and $3=$ points situated at 200,400 and 600 m altitude, along cuchillos; $4=$ cuchillos; $5=$ palaeo-contours of the volcano; $6=$ dykes related with both the foci; $7=$ other dykes; $8=$ converging area estimated for dykes related to southern focus; $9=$ idem for northern focus; $10=$ Basal Complex; $11=$ post-OBS materials. OBS $=$ area in white. $G T=$ Gran Tarajal; $P=$ Pájara; $T O=$ Toto; $T U=$ Tuineje. 


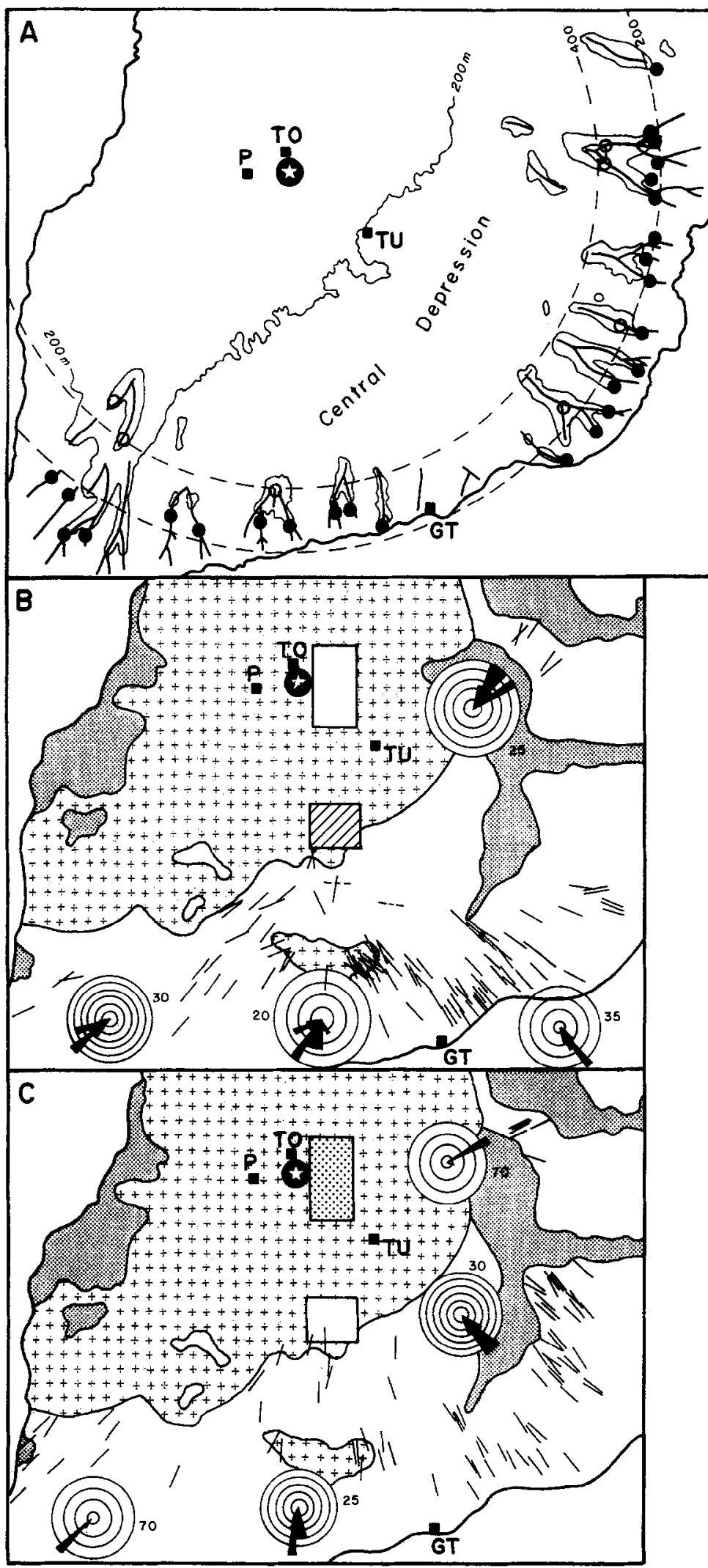

- $1=$

o $2=7$

* 3 EDT

$<4$ बन

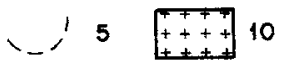

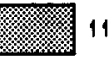

$0 \quad 2 \quad 4 \mathrm{~km}$

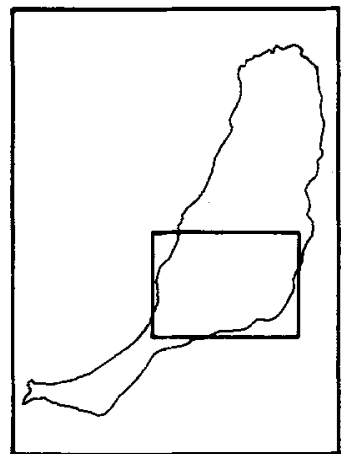


forming a series of middle alkaline affinities. There also exist local exposures of undersaturated peralkaline trachytes (Muñoz, 1969; Esnaola, 1984; Cubas et al., 1988) as plugs, flows and dykes that appear to be related to it.

The Central Volcanic Complex III (CVC-III) forms the uppermost part of many of the "cuchillos", overlying either in unconformity or in apparent conformity the two older episodes. Exceptionally in the western sector the CVC-III materials overlie the $\mathrm{BC}$. They form a $200-300 \mathrm{~m}$ succession of thick basaltic and trachybasaltic lava flows. Since the exposures are not continuous, their correlation is often difficult.

As in the case of the SVC, the converging "cuchillos" form a radial distribution, as the remains of a volcanic construct, although in this case erosion is much more intensive and the structure more complex. By applying the same method as in the case of the SVC, the heights corresponding to 200 and $400 \mathrm{~m}$ palaeocontours (at current altitude) define a cone centered near Toto (Fig. 4A).

The CVC features more local exposures, referred here as Melindraga, Tamacite and Los Tableros formations (Late formations, Ancochea et al., 1991). Smaller in terms of volume, these rocks were extruded after the formation of the Central Depression (Fig. 2B) and when the relief, although less subdued than at present, might well have been similar in appearance to today.

The first and most important of these formations originates from the $\mathrm{BC}$ area where the so-called Montaña Melindraga represents the highest topographic exposure and hence the nearest to the eruptive center. Here, a clear uncorformity and a detrital sequence are observed between this formation and the underlying intensely weathered $\mathrm{BC}$ rocks. The total thickness is about $150 \mathrm{~m}$ and is accounted for by at least seven thick alkali basalt and trachybasalt flows. From the high $\mathrm{BC}$ area these flows descended to the Central Depression filling a deep paleovalley and fossilizing the relief excavated in the SVC-I and SVC-II.

\subsubsection{Dyke systems}

Dykes in the southeastern and southwestern areas of this volcanic complex are abundant and have been mentioned by several authors (Fúster et al., 1968a; López Ruiz, 1970; Feraud, 1981). Those NW-SE trending in Gran Tarajal, NE-SW trending near " $\mathrm{El}$ Jable" and, finally, those in the BC area (N10-N $\left.30^{\circ}\right)$ are specially abundant and seem to form a triple trend. However, dykes are also frequent (sometimes one every $5 \mathrm{~m}$ ) out of these main bands all through the eastern and southern flanks of the CVC giving rise to a radial trend. Dykes are more abundant in the CVC-I, less so in the CVC-II, and virtually non-existent in the CVC-III as well as in the Melindraga, Tamacite and Tableros formations.

All dykes and "cuchillos" roughly converge in the same sector, but if analyzed in detail by the computer method of Brändle et al. (1991) two different convergent dyke sets can be distinguished. In fact, two different strikes separated by $20^{\circ}$ are often observed in the same zone (Fig. $4 \mathrm{~B}$ and C). Hence, two different centers (northern and southern focus) are inferred. The southern focus appears to be younger and might correspond to the CVC-II, while the northern focus would represent the center of the CVC-I.

\subsubsection{Age}

None of the dates available may be attributed with certainty to the CVC-I. Only one age given by Balcells et al. (1994), in view of its stratigraphic position, might correspond to it, although the age $(30.47 \pm 1.47 \mathrm{Ma})$ seems rather too old; the sample, however, is intensely weathered, and further support would be required.

Ages obtained from OBS flows by Coello et al. (1992) should be ascribed to the CVC-II (Table 3). Two flows dated by them at $20.4 \mathrm{Ma}$ (redated to $20.95 \mathrm{Ma}$ ) and $18.3 \mathrm{Ma}$ (redated to $20.01 \mathrm{Ma}$ ) and some others dated by Balcells et al. (1994) at 22.5, 21.7-21.1 and 21.1-20.0 Ma should be also included here. An age of $21.5 \mathrm{Ma}(\mathrm{CPN}-4)$ was obtained in this study for a lava flow above sediments resting unconformably on the CVC-I and could therefore be ascribed to the CVC-II. Many of the dykes dated by Feraud et al. (1985) at 19.9 and 20.0 Ma would also correspond to it.

Some other ages may be attributed to the CVC-III, such as those obtained by Coello et al. (1992) for a flow at the top of a "cuchillo" in the northeast (15.4 $\mathrm{Ma})$, for a plug cutting into it (15.6 Ma) and for a flow resting directly on the $\mathrm{BC}(14.5 \mathrm{Ma})$. We have also dated a sample from the top of a "cuchillo" in 


\section{E. Ancochea et al.}

Table 3

Radiometric K-Ar ages in the Central Volcanic Complex

\begin{tabular}{lllll}
\hline Sample No. & $\% \mathrm{~K}$ & ${ }^{40} \mathrm{Ar} \mathrm{rad}$ & $\% \mathrm{Ar}$ atm & $\mathrm{Ag}(\mathrm{Ma})$ \\
\hline 92880 & 1.21 & $1.065 \mathrm{nl} / \mathrm{g}$ & 58.80 & $21.50 \pm 0.83$ \\
$(\mathrm{CPN}-4)^{\mathrm{a}}$ & & & & \\
Fue-24 $^{\mathrm{a}}$ & 0.98 & $0.790 \mathrm{nl} / \mathrm{g}$ & 36.74 & $20.93 \pm 0.74$ \\
Fue-24 $^{\mathrm{b}}$ & 0.98 & $1.392 \mathrm{ng} / \mathrm{g}$ & 30.43 & $20.40 \pm 0.40$ \\
Fue-27 $^{\mathrm{a}}$ & 1.01 & $0.787 \mathrm{nl} / \mathrm{g}$ & 20.53 & $20.01 \pm 0.68$ \\
Fue-27 $^{\mathrm{b}}$ & 1.01 & $1.297 \mathrm{ng} / \mathrm{g}$ & 21.96 & $18.30 \pm 0.30$ \\
$92012^{\mathrm{a}}$ & 0.97 & $0.520 \mathrm{nl} / \mathrm{g}$ & 42.97 & $18.29 \pm 0.69$ \\
$92886^{\mathrm{a}}$ & 0.68 & $0.442 \mathrm{nl} / \mathrm{g}$ & 48.61 & $17.55 \pm 1.01$ \\
$92011^{\mathrm{c}}$ & 2.06 & $1.335 \mathrm{nl} / \mathrm{g}$ & 87.7 & $16.6 \pm 0.8$ \\
Fue-59 $^{\mathrm{a}}$ & 1.64 & $1.036 \mathrm{nl} / \mathrm{g}$ & 23.93 & $16.19 \pm 0.51$ \\
Fue-59 $^{\mathrm{b}}$ & 1.64 & $1.768 \mathrm{ng} / \mathrm{g}$ & 22.45 & $15.40 \pm 0.34$ \\
Fue-56 $^{\mathrm{b}}$ & 1.39 & $0.795 \mathrm{nl} / \mathrm{g}$ & 87.4 & $14.7 \pm 0.7$ \\
\hline
\end{tabular}

${ }^{a}$ Ages obtained at the Laboratory of Geochronology, Univ. Complutense, Madrid (Spain).

${ }^{b}$ Ages after Coello et al. (1992) obtained at the Geological Department, CNRS-Univ. Clermont-Ferrand (France).

${ }^{c}$ Ages obtained at the Laboratory of Teledyne Isotopes (USA).

the southeastern area, for which we have obtaincd an age of $14.7 \mathrm{Ma}$ (Table 3). Thus, its age can be estimated as being between 15.6 and $14.5 \mathrm{Ma}$.

One of the main unresolved problems concerned the age of the "formations". We have dated the Melindraga Formation at $18.29 \pm 0.69$ and $16.6 \pm 0.8$ $\mathrm{Ma}$. In view of its stratigraphic position, a flow dated by Balcells et al. (1994) at $16.45 \pm 0.72$ Ma may also be interpreted as belonging to it. The Tamacite Formation has given an age of $17.55 \pm 0.1 \mathrm{Ma}$. Both the formations represent the activity that took place once the Central Depression had already formed and prior to the development of the CVC-III.

The debris-flow deposits V3, V2, and V1 from DSDP hole 397 contain microgabbro fragments that were interpreted by Schmincke and Von Rad (1979) as originating from the $\mathrm{BC}$ on Fuerteventura. Their age coincides with important activity in the SVC, although the $\mathrm{BC}$ does not crop out there. By contrast, the Melindraga and Tamacite formations directly overlie the $\mathrm{BC}$, indicating that the latter was already being eroded when these formations were erupted. The age attributed by Schmincke and Von Rad (1979) to those deposits (17.2 and 16.5 Ma) is in agreement with those obtained for the formations mentioned above.

The age of the Los Tableros Formation was calculated by Coello et al. (1992) as being 13.2 Ma, thus representing a much later activity, which, as we will see further on, must have been related to the NVC.

\subsection{The Northern Volcanic Complex}

The remains of the Northern Volcanic Complex (NVC) extend from the OBS northermost exposures to the CVC. The geomorphological areas established before for the CVC are also observed in this sector. The OBS crops out mainly in the north and east, while the $\mathrm{BC}$ is exposed to the west and southwest (Fig. 1). Both are partially overlain by younger volcanics (Recent Series) and sediments. The best OBS exposures occur as high "cuchillos" on the western area, contrasting with other zones where the OBS appears as scattered plain exposures at the bottom of the Central Depression or as a succession of low hills in the northwestern sector.

Two constructives episodes are distinguished in this volcano: the NVC-I and the NVC-II. The agglomerate known as the Ampuyenta Formation is located between them (Table 1; Fig. 2C).

The Northern Volcanic Complex I (NVC-I) occurs in the Central Depression in the northwestern sector, and at the base of the highest "cuchillos". As it is partially covered by younger deposits, the structure is not clearly observed, although where it can be seen it appears to be subhorizontal. Nevertheless, three different units have been established. The lower unit (Lower NVC-I) consists of numerous picritic basaltic flows intensely traversed by a network of dykes, in which dykes are spaced 2-5 $\mathrm{m}$. Contact with the underlying $\mathrm{BC}$ rocks is continuous, whereas it appears that there is a tectonic junction with the overlying unit. The next unit (Middle NVC-I), which is of similar composition, is cut by two main dyke systems, although dykes are wider spaced $(10 \mathrm{~m})$ and also present fracturation. The third unit (Upper NVC-I or Oliva and Lajares formations of Hernán et al., 1993) is represented by more than a $100 \mathrm{~m}$ thickness of subhorizontal oceanitic basalts and trachybasalts of mildly alkaline affinity (Table 2). The intensity of dykes is much lower in this unit.

Oversaturated alkaline trachytic plugs and dykes are present in the area of Tindaya (Muñoz, 1969; Cubas et al., 1988). According to field observations, these may be ascribed to this NVC-I, possibly to its upper unit. 
The Ampuyenta Formation is up to $200 \mathrm{~m}$ thick and it is formed mainly by agglomerate, sometimes bedded, with very scarce interlayered flows. The formation has been interpreted in many ways: as nuée ardente and laharic deposits; piedmont conglomerates; or avalanches and lahars (Hausen, 1958; Fúster et al., 1968a, 1984a, b; Ancochea et al., 1993). Some authors have considered it to be the OBS substratum (Hartung, 1857; Bourcart and Jeremine, 1938; Hausen, 1958; Rothe, 1966).

The agglomerates are exposed at the base of the inner flank of the "cuchillos" south of La Oliva. They lie unconformably over the NVC-I and, according to Fúster et al. (1984a, b), over the BC rocks also. All dykes cutting through this formation belong to one single system, the same one as in the NVC-II. The fact that most fragments come from lava flows would indicate that the Ampuyenta Formation was derived by erosion of an older subaerial edifice. This could not be the CVC since the thickness of the Ampuyenta Formation decreases southwards. The source for the agglomerates must be closer and could be the NVC-I. The absence of this formation north of La Oliva points to this zone as the main source area. Furthermore, the existence of plutonic rocks as clasts in this formation in some sectors indicates that the $\mathrm{BC}$ had already emerged by then.

The Northern Volcanic Complex II (NVC-II) consists of a succession of eastwards dipping lava flows more than $300 \mathrm{~m}$ thick where long and narrow "cuchillos" have been carved. It lies unconformably above the Ampuyenta Formation; sedimentary levels frequently occur at the contact and pahoehoe lavas predominate at the base of the succession. Basalts are dominant but more evolved types (Table 2) are abundant. Plagioclase-rich basalt is the most abundant basalt type and all rocks are alkaline. The NVC-II overlaps the CVC south of Puerto del Rosario where the "cuchillos" are formed by CVC-III materials at their base and by NVC-II ones at the top, separated by well-developed sedimentary levels.
The structure and morphology now observed in the NVC is essentially that of the NVC-II. Although in this case the "cuchillos" are not as markedly radial as in the CVC and SVC, they do still present a circular pattern with the highermost point inwards. Most "cuchillos" join at the headwaters zone, giving rise to an almost continuous scarp that constitutes the eastern margin of the Central Depression (Fig. 5A). As in the two previous examples, the palaeocontours obtained by joining points of relict topography of similar height locate the center west of the cone in the area where the $\mathrm{BC}$ is now exposed.

\subsubsection{Dyke systems}

We have separated basaltic dykes cutting through the NVC-II, those traversing the NVC-I and felsic dykes. It can be seen that dykes are much less abundant in the former (Fig. 5B) than in the latter (Fig. 5C).

In the NVC-II, dykes form a radial trend converging in an arca sited in the Central Depression near Los Molinos and coinciding with the center deduced from morphological data above. The abundance of dykes also increases towards the center. Al! the dykes that may be interpreted as belonging to it, that is, all those included in the radial trend, are shown in Fig. 5B. The Ampuyenta Formation is traversed by as many dykes as the NVC-II, and hence none of them would correspond to this destructive period.

Interpretation of the dykes in the NVC-I is difficult since they are abundant and show very different strikes. Dykes that can be interpreted as exclusively belonging to it are shown in Fig. 5C. They all appear to converge in an area situated between Oliva and Toston, although mathematical analysis (Brändle et al., 1991) does not afford conclusive results.

\subsubsection{Age}

Coello et al. (1992) dated several samples from the NVC-II as being between 14.3 and $12.8 \mathrm{Ma}$. An agglomeratic level, situated above a lava flow dated

Fig. 5. Northem Volcanic Complex. (A) Morphological sketch and reconstruction. (B) Dykes in the NVC-II. (C) Dykes in the NVC-I. In (B) unidirectional rose diagrams for dykes in each sector. 1,2 and $3=$ points situated at 200,400 and $600 \mathrm{~m}$ altitude, along cuchillos; $4=$ morphological center; $5=$ cuchillos; $6=$ central scarp; $7=$ palaeo-contours of the volcano; in (B) $8=$ dykes cutting the NVC-I and belonging to the NVC-II, in (C) $8=$ salic dykes in the NVC-I; $9=$ converging area estimated for dykes in the NVC-I; $10=\mathrm{Basal}$ Complex; $I I=$ post-OBS materials. OBS $=$ area in white; $L=$ Lajares; $L M=$ Los Molinos; $O L=$ Oliva; $T C=$ Tostón Cotillo; $T I=$ Tindaya; $P R=$ Puerto del Rosario. 


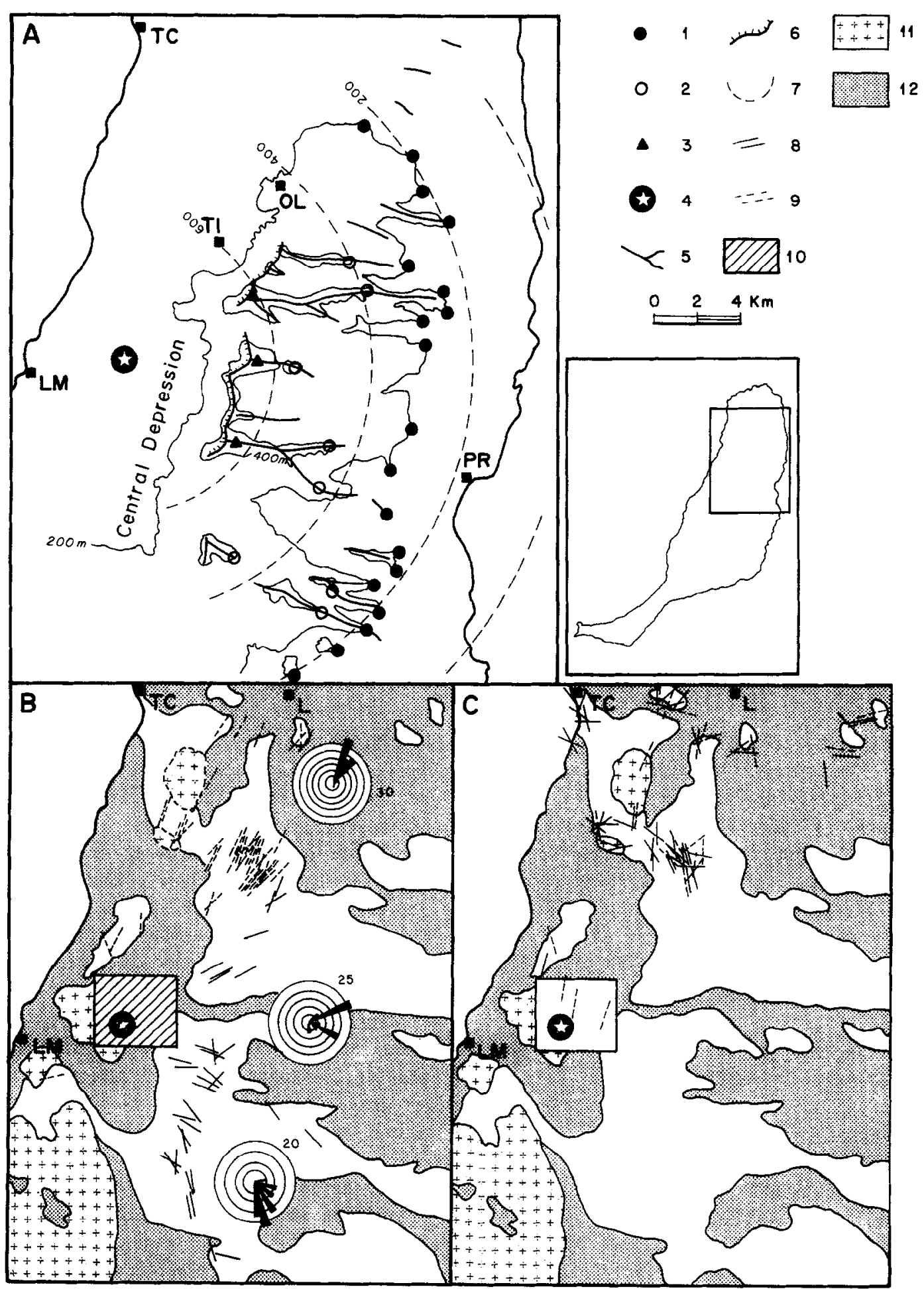


Table 4

Radiometric K-Ar ages in the Northern Volcanic Complex

\begin{tabular}{lccll}
\hline Sample No. & $\% \mathrm{~K}$ & ${ }^{40}$ Ar rad & \%Ar atm & Age (Ma) \\
\hline $93900(\mathrm{Ne}-1)$ & 1.08 & $1.270 \mathrm{nl} / \mathrm{g}$ & 52.64 & $31.46 \pm 1.12$ \\
$93870(\mathrm{Ne}-7)$ & 0.79 & $0.489 \mathrm{nl} / \mathrm{g}$ & 55.92 & $17.0 \pm 0.85$ \\
$93873(\mathrm{Ne}-10)$ & 0.93 & $0.505 \mathrm{nl} / \mathrm{g}$ & 83.62 & $15.34 \pm 1.26$ \\
\hline
\end{tabular}

Ages obtained at the Laboratory of Geochronology, Univ. Complutense, Madrid (Spain).

at 13.6 Ma has been interpreted by Coello et al. (1992) as part of the Ampuyenta Formation, but in our opinion, and in agreement with Martín (1984), this agglomeratic level does not belong to the Ampuyenta Formation.

There are three ages belonging to the NVC-I: $17.0 \pm 0.85 \mathrm{Ma}, 15.34 \pm 1.26 \mathrm{Ma}$ (Table 4) and 16.1 $\mathrm{Ma}$ in Tostón-Cotillo, this last one dated by Abdel Monem et al. (1971) as being 21.2 Ma and redated by Coello et al. (1992) to $16 \mathrm{Ma}$. This flow unconformably overlies older rocks which are densely traversed by dykes that we interpret as being the Lower NVC-I, for which the only available age ( 31.5 $\mathrm{Ma}$ ) corresponds to a flow further south overlying the $\mathrm{BC}$ and also intensely traversed by dykes. Due to a certain degree of hydrothermal weathering of the sample, this age should be treated with caution. A trachyte in Tindaya $(18.7 \mathrm{Ma})$ should be interpreted as corresponding to the NVC-I too.

Finally, Rona and Nalwalk (1970) have dated a number of dykes cutting through the BC (Fig. 1), two of which (14.4 and $12.1 \mathrm{Ma}$ ) correspond to the NVC-II dyke swarm. Three other dykes dated at 22.3, 23.3 and $18.0 \mathrm{Ma}$ might be related to the Lower or Middle NVC-I.

\section{Submarine prolongation of volcanic complexes}

Both the morphology and the dyke systems indicate the occurrence of large volcanoes whose centers are situated offshore in the case of SVC and onshore in the cases of CVC and NVC. The prolongation beneath sea level should therefore be reflected in the bathymetric contour lines (Nat. Geogr. Inst. of Spain, Topographic Map, 1:200.000, 1982). As shown in Fig. 6, depth increases gently from 0 to $100 \mathrm{~m}$ and then abruptly from 100 to $500 \mathrm{~m}$ in less than $1 \mathrm{~km}$ horizontal distance. However, depending on the sector this abrupt inflexion occurs at a different distance from shore.

On the southern flank of the SVC, the submarine floor descends rapidly, whereas along the northern coastal line the submarine slope is gentle. This would indicate that it at one time must have extended further north. The center of the submerged relief coincides with that deduced from the morphology and dyke systems, which would lend support to the hypothesis of a large central volcano occupying this area.

On the central part of Jandía peninsula, the arcuate shape adopted by isobaths may denote a northward slide causing a nearly $12 \mathrm{~km}$ wide depression. The Jandía escarpment probably originated as a consequence of that slide. The scarp may have retroceded later through erosion. The dyke trends $\mathrm{N} 50^{\circ}$ (west of Jandía) and N90-N100 (east) may have conditioned the present arcuate wall shape.

The slope is steep on the northern submarine flank of the NVC, more gentle southwards, denoting a certain circular shape, and the submarine western floor is much flatter. These facts supports the idea that the NVC was centered west onshore.

On the western flank of the CVC the submarine slope dip is gentle, the same as along the southern margin. This indicates that it extended further into the sea. In fact, the "cuchillos" in the NVC gently disappear onshore a certain distance from the coastline, while those in the CVC extend further and exhibit erosion cliffs at the coast which exists today. The $100 \mathrm{~m}$ isobath may be an approximate reflection of the original shape of these volcanoes.

The eastern flank of the CVC is, as in the case of the NVC, flatter, a circumstance which would also support the existence in this area of a large central volcano centered west onshore.

Bathimetry also attests to the occurrence of two seamounts west of Jandía (Fig. 6). Both seamounts show circular shapes that can be interpreted as corresponding to independent edifices. The first one, situated northwest of Jandia, is given the name here "Amanay Submarine edifice". The second seamount occurs southwest of Punta de Jandía, and designated in this paper as "El Banquete Submarine edifice", is connected to the SVC by a flat and shallow (20-30 $\mathrm{m})$ platform. Both the seamounts are similar in size 
and are separated from each other by a narrow furrow which is more than $1000 \mathrm{~m}$ deep.

The elongated southern submarine prolongation of the CVC does not match that expected for a central volcano. Its alignment with the nearby dykes intruding into the CVC-I enables it to be considered as a submarine prolongation of this sheeted dyke swarm. The narrow isthmus of "El Jable" could be the result of a similar situation, which would thus explain the absence of a submarine furrow between the CVC and SVC. The flat area located between the two volcanoes could also be explained in this way. The great intensity of $\mathrm{N} 40-\mathrm{N} 50^{\circ}$ dykes at the south- western side of Jandia parallels the trend defined by the alignment of both volcanic complexes.

On the other hand, a short distance from Fuerteventura, on Lanzarote, two other old massifs, Los Ajaches and Famara, in the southwestern and northeastern part (Fig. 6), respectively, are found (Fúster et al., 1968b). Los Ajaches was essentially built up between 15 and $12 \mathrm{Ma}$ (Ibarrola et al., 1988; Coello et al., 1992) and is therefore partly contemporaneous with the NVC-II on Fuerteventura. By contrast, Famara is less than $10 \mathrm{Ma}$. If the surrounding bathymetric lines are observed, these two massifs may also be interpreted as being the remains of two

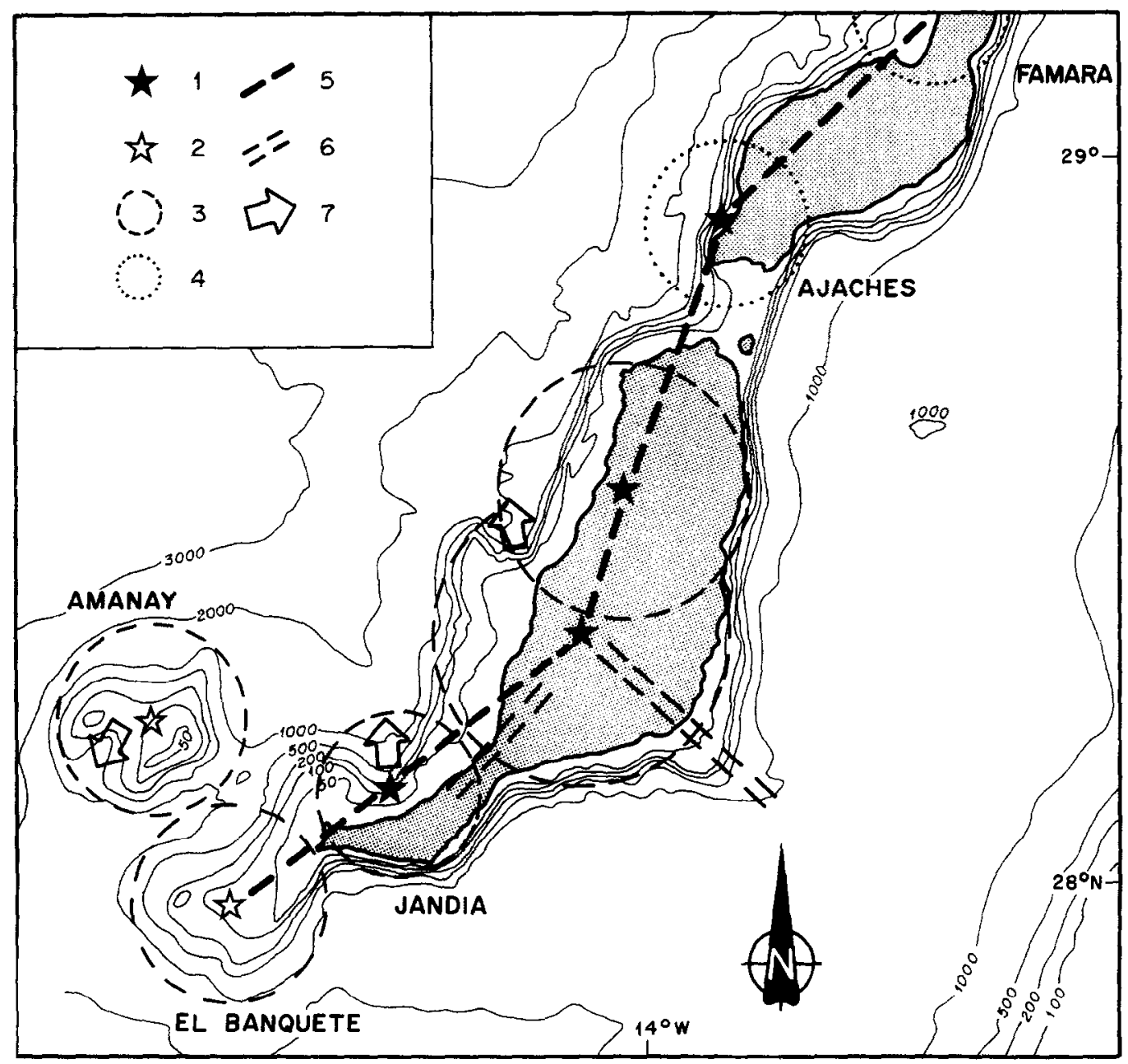

Fig. 6. Location of the OBS volcanic complexes on Fuerteventura and Lanzarote. $1=$ subaerial emission centers; $2=$ submarine emissions centers; $3=$ approximated areas occupied by the volcanic complexes in Fuerteventura zone; $4=$ idem in Lanzarote zone; $5=$ alignement of the volcanoes; $6=$ main trends of dyke intrusions; $7=$ possible landslides. 
other old volcanoes which were larger than the current emergent exposures. If so, the top of the Eastern Canarian Volcanic Ridge is formed by a chain of large central volcanoes roughly parallel to the African coastline.

Table 5 shows the main geometrical characteristics of all the different OBS volcanoes on the Eastern Canarian Volcanic Ridge. Subaerial volcano diameters are estimated for areas bounded by the $100 \mathrm{~m}$ isobath, and taking into account the centers deduced from dyke systems. Maximum submarine diameters are calculated taking into account the depth at which the shield shape is clearly inferred. The largest one is the CVC, followed by its NVC and SVC counterparts. The Amanay and $\mathrm{El}$ Banquete submarine edifices can be compared to the Ajaches or even to the island of El Hierro, which is about $32 \mathrm{~km}$ wide where the depth reaches $1000 \mathrm{~m}$.

We have also estimated volcano heights. Hawaian shields are characterized by slope dips of between 3 and $10^{\circ}$ while the average figure for alkaline composite volcanoes is $12^{\circ}$ (Peterson and Moore, 1987). If we consider slopes of between 7 and $9^{\circ}$, heights will range from 1600 to $2100 \mathrm{~m}$ for the SVC, from 2300 to $3000 \mathrm{~m}$ for the NVC and from 2600 to 3300 $\mathrm{m}$ for the CVC. On the basis of $\mathrm{O}$ and $\mathrm{H}$ isotope studies in samples from central Fuerteventura, Javoy et al. (1986) have deduced the existence of a volcano

Table 5

Geometrical features of volcanocs

\begin{tabular}{llll}
\hline & $\begin{array}{l}\text { Submarine } \\
\text { basal } \\
\text { diameter } \\
(\mathrm{km})\end{array}$ & $\begin{array}{l}\text { Subaerial } \\
\text { diameter } \\
(\mathrm{km})\end{array}$ & $\begin{array}{l}\text { Height } \\
(\mathrm{km})^{\mathrm{a}}\end{array}$ \\
\hline $\begin{array}{l}\text { Submarine } \\
\text { Amanay }\end{array}$ & 29 & - & - \\
Fl Banquete & 28 & - & - \\
$\begin{array}{l}\text { Fuerteventura } \\
\text { Southem V.C. }\end{array}$ & 34 & 26 & $1.6-2.1$ \\
Central V.C. & 49 & 42 & $2.6-3.3$ \\
Northern V.C. & 43 & 38 & $2.3-3.0$ \\
Lanzarote & & & \\
Ajaches & 28 & 18 & $1.1-1.4$ \\
Famara & - & 16 & $1.0-1.3$ \\
\hline
\end{tabular}

a Theoretical slope to calculate the height of the volcano is $6-9^{\circ}$. between 2500 and $4000 \mathrm{~m}$ high, which would tally with our own estimation for the primitive CVC.

\section{Discussion}

\subsection{Structural trends}

The alignment defined by the chain of volcanoes found in Fuerteventura and Lanzarote extends further north up to Banco de la Concepcion, a submarine volcanic complex (Fig. 7) situated above $30-31^{\circ} \mathrm{N}$ latitude (Luyendyk and Bunce, 1973; Uchupi et al., 1976; Weigel et al., 1978; Dañobeitia, 1988; Dañobeitia and Collette, 1989). This alignment constitutes the eastern branch of the Canary Ridge, within which three roughly $\mathrm{N} 50^{\circ}$-trending subparallel branches are distinguished.

The sheeted dyke net in the $\mathrm{BC}$, featuring a $>80 \%$ lateral spreading along its axial zone (Stillman, 1987), marks the main spreading trend in the area and, therefore, the main regional trend. It is along this $\mathrm{N} 15^{\circ}$ trend that the NVC and CVC centers on Fuerteventura, as well as Los Ajaches on Lanzarote, are also aligned. This coincides with the Central Depression northern branch trend.

On the other hand, the CVC and the SVC, together with the El Banquete seamount, feature a second $\mathrm{N} 230-\mathrm{N} 235^{\circ}$ trend which parallels that of dykes in the "El Jable" area and intruding into the SVC-I and CVC-1. The northeastern coast of Jandía, the southern margin of the up-lifted $\mathrm{BC}$ relief and even the southern branch of the Central Depression show this same trend. Further north on Lanzarote, the alignment of Los Ajaches and the Famara massifs could represent a repetition of the $\mathrm{N} 230-\mathrm{N} 235^{\circ}$ trend.

The $\mathrm{N} 135^{\circ}$ dykes on southeastern Fuerteventura (Gran Tarajal) and their submarine prolongation (Fig. 6) could constitute the third arm of a possible triple junction. In any case it must be emphasised that the first and the second trends represent long-lived regional tectonic lineations while the third one has been aborted.

\subsection{Tectonic phases}

Apart from pre-Miocene tectonics printed in the earliest rocks of the $\mathrm{BC}$ (Rothe, 1968; Robertson and 
Stillman, 1979a, b; Robertson and Bernoulli, 1982; Casillas et al., 1994), an important Miocene tectonics is also present, as attested to not only by the occurrence of frequent local cataclastic levels but also by the existence of the Central Depression, the $\mathrm{BC}$ exposures above sea level and possibly the disappearance of the western halves of the NVC and the CVC, though this last fact need not be tectonic.

Bourcart and Jeremine (1938), Hausen (1958) and Bravo (1964) explain the origin of the northern Jandía coastline and the Central Depression by fractures. In fact, the landslide of the SVC northern half must have been propitiated by the presence of an important $\mathrm{N} 40-\mathrm{N} 50^{\circ}$ fracture system that conditioned the eastern margin of the northern coast of Jandia. This system of fractures and dykes penetrates into the $\mathrm{CVC}$ to form the main $\mathrm{BC}-\mathrm{OBS}$ boundary.

The CVC-I lava flows dip $30-35^{\circ}$, rather more than is usual in this type of succession and are considerably more inclined and fractured than lavas belonging to the CVC-II. These facts point to the existence of a tectonic event which occurred between the CVC-I and CVC-II. Bearing in mind the dip observed, the up-lifted block would coincide with the area where the $\mathrm{BC}$ is exposed. This would represent an earlier tectonic phase within the OBS, prior to the CVC-II and therefore more than $22 \mathrm{Ma}$ old (Table 6).

A second tectonic phase took place after the CVC-II was formed and before the eruption of the Melindraga and Tamacite formations. These formations which directly overlie the $\mathrm{BC}$ were erupted when the Central Depression had already been created. Their age would be between 20 and $19 \mathrm{Ma}$, the age of the most recent rocks in the CVC-II, and 17.5 and 16.5 Ma, which is that of the Melindraga and

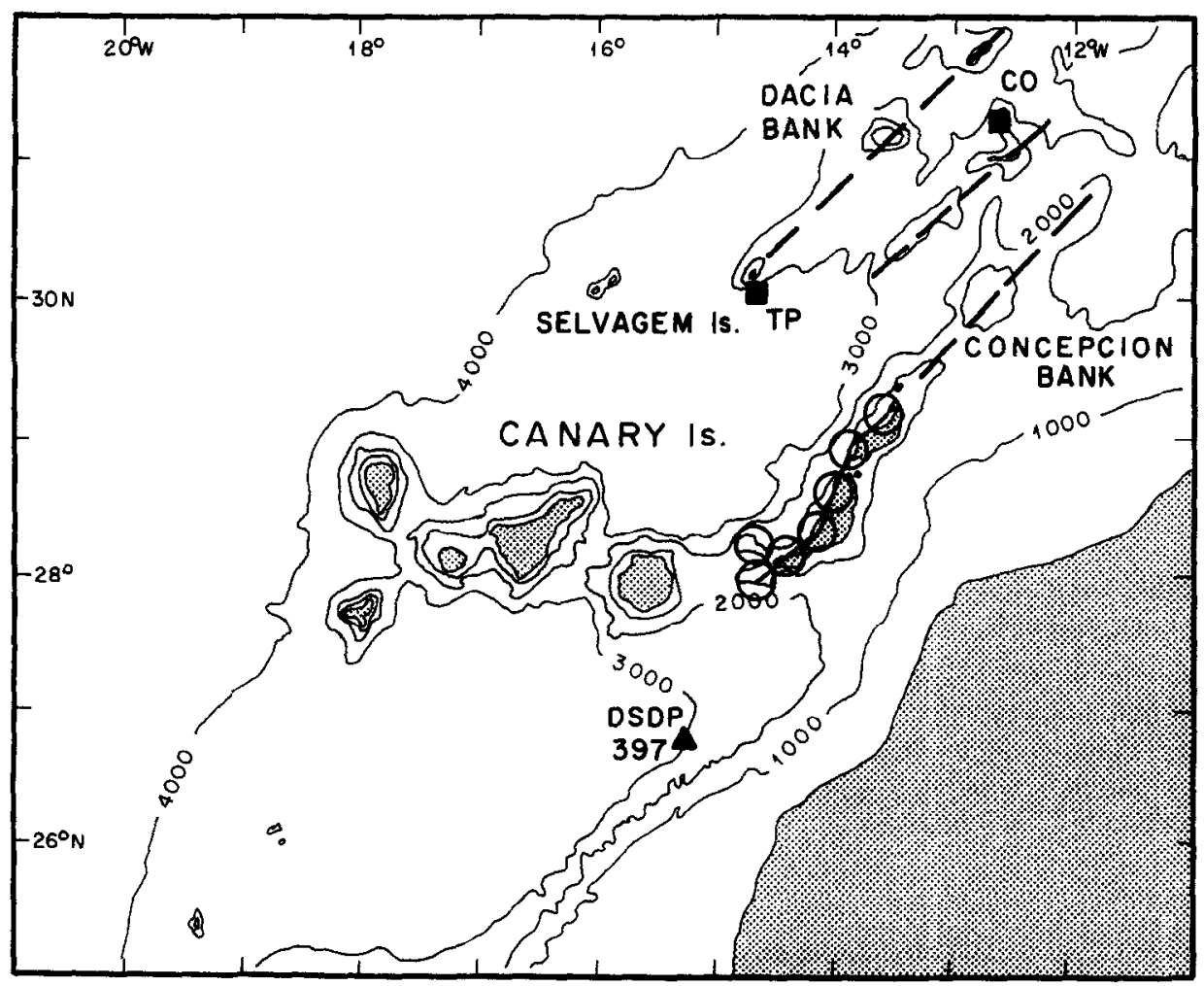

Fig. 7. General sketch of the Canary Islands modified after Dañobeitia and Collette (1989). $\Delta=$ DSDP site 397 ; $\square=E l$ Topete, $T P$, and Complutense, $C O$, submarine volcanic edifices. $O=$ major volcanic complex in Lanzarote and Fuerteventura zone. Dashed lines $=$ branches of the Canary Ridges. 
Tamacite formations. The debris flow found in DSP hole 397 , which reflects substantial mobility in the area, coincides with this age.

The unconformity between the SVC-I and the SVC-II occurred at the same time (19.3-17 Ma). Lastly, the period is also represented in the NVC by the quiescence reflected within the NVC-I by the separation between the strongly tectonised Middle NVC-I and the Upper NVC-I, where tectonics is virtually nonexistent.

The Ampuyenta Formation may relate to a third tectonic phase prior to the NVC-II $(>14.3 \mathrm{Ma})$, which probably coincided with the quiescence period that separated the SVC-II from the SVC-III (Table 6).

\section{3. $B C-O B S$ relationships}

The model developed in this work for the subaerial volcanic activity introduces important changes in the interpretation of the $\mathrm{BC}$. This new interpretation is based on the following observations:

(a) The main BC exposures are located at the core of major subaerial volcanic complexes.

(b) There is no single regional BC-OBS unconformity but rather different relationships between some units and the $B C$ rocks.

(c) According to the K-Ar age data the subaerial units and some $\mathrm{BC}$ episodes are contemporaneous (see Table 6).

(d) There are several independent OBS volcanic complexes overlying their corresponding independent $\mathrm{BC}$ exposures.

(e) In the same way that the subaerial volcanic complexes are the result of different overlapping constructs, the BC exposures are the result of different successive intrusion episodes.

The BC crops out in two different areas (Fúster et al., 1968a). The most extensive is situated in the core of the CVC and is thus given the name here "Central Basal Complex" (CBC). CBC submarine volcanics lie at the periphery, whereas intrusive rocks are concentrated in the innermost zone, coinciding with the center deduced from dyking in the CVC-I and CVC-II.

The second $\mathrm{BC}$ exposure, denoted here Northern Basal Complex (NBC), also occurs in two different sectors. The southernmost sector coincides with the center deduced for the NVC-II, while the other might occupy the nucleus of the NVC-I. A geometrical relationship between $\mathrm{BC}$ exposures and $\mathrm{OBS}$ volcanoes can therefore be inferred.

The BC-OBS unconformities quoted in the literature in fact represent unconformities between $B C$ rocks and relatively late OBS levels. For example, the unconformity in the NVC occurs between the BC and the Ampuyenta Formation or between the $\mathrm{BC}$ and the Upper NVC-I. In the case of the CVC, the unconformity is between $\mathrm{BC}$ rocks and the overlying CVC-III or even the Tamacite and Melindraga formations. On the contrary, when a (non-tectonic) contact is observed between $B C$ rocks and early constructive episodes of the NVC or CVC, submarine volcanics are always involved, but never plutonics.

The oldest rocks in the $\mathrm{BC}$ are Mesozoic turbidites (Rothe, 1966) with interlayered volcanoclastic sediments (Robertson and Stillman, 1979a, b; Robertson and Bernoulli, 1982). This sequence appears inverted on its southern exposure as part of a reclined NE-facing neutral fold which points to the existence of an earlier tectonic phase in the area, which would have occurred shortly after the onset of volcanism on Fuerteventura but prior to the moment when the island emerged.

The overlying submarine volcanics not affected by earlier folding are interlayered at the top with shallow fossil-bearing sediments of Early and middle Oligocene age (Robertson and Bernoulli, 1982). These submarine rocks have also given Oligocene radiometric ages of $36.3 \mathrm{Ma}$ (a recalculated age of Abdel Monem et al., 1971) and 35.7 Ma (Ibarrola et

Notes to Table 6:

[1] Rona and Nalwalk (1970); [2] Abdel Monem et al. (1971); [3] Grunau et al. (1975); [4] Le Bas (1981); [5] Ibarrola et al. (1989); [6] Cantagrel et al. (1993).

$\mathrm{O}=$ age in $\mathrm{Ma} ; \sim \sim \mathrm{F} \sim \sim$ tectonic phase; $\mathrm{CPG}=$ Central Plutonic Group; NPG $=$ Northern Plutonic group. 


\section{E. Ancochea et al.}

Table 6

Main events in the growth of volcanic complexes and intrusion episodes

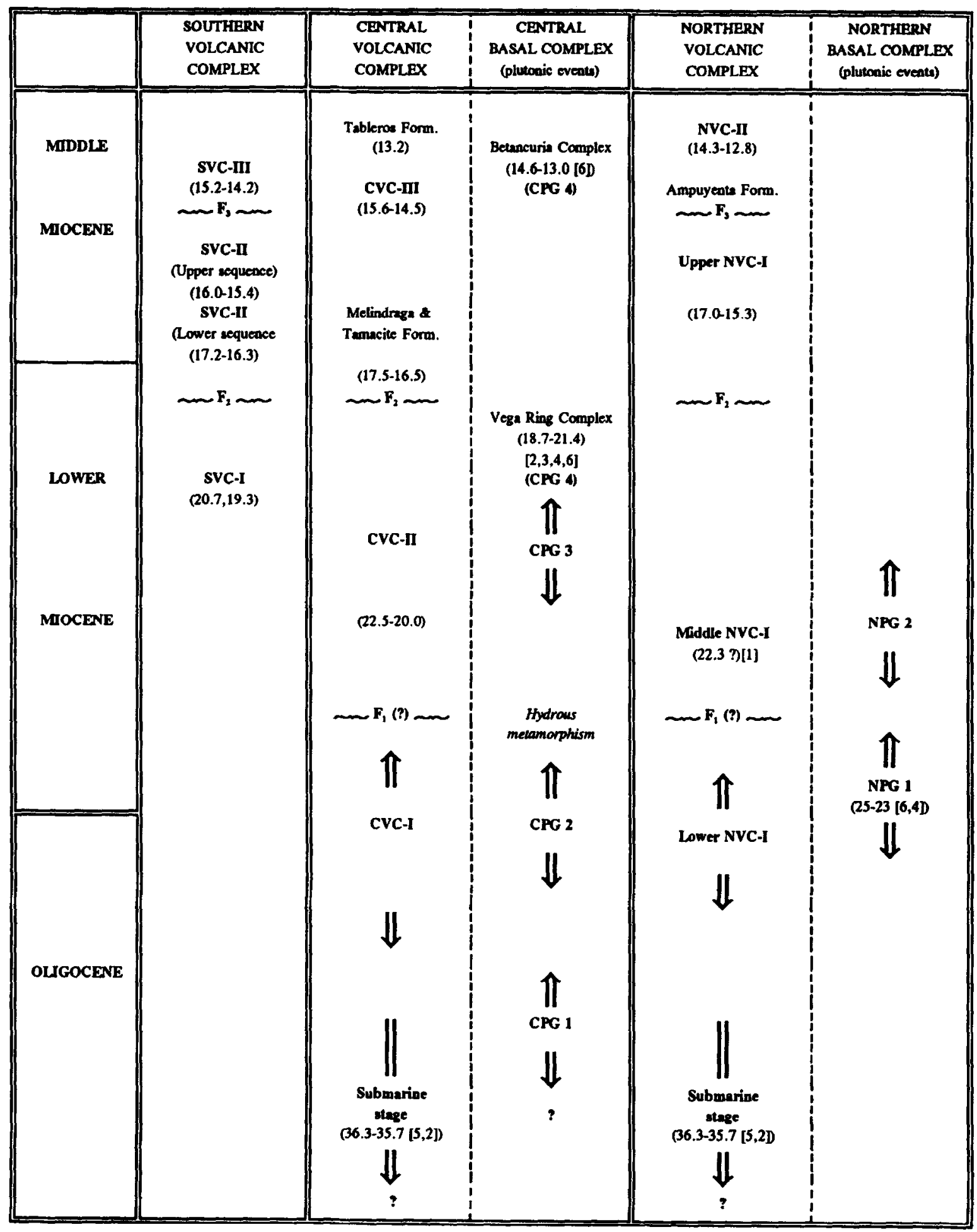


al., 1989) as shown in Table 5. This whole set of rocks is cut by intensive dyking representing between 50 and $100 \%$ of the outcrop, which makes the observation of rock relationships difficult. The top of the submarine succession corresponds to a stage when the island was nearly emerging, as shown by the existence of shallow sediments and greater abundance of hyaloclastites.

It is not possible currently to establish temporal differences between the submarine succession of the CVC and NVC, since the age data available correspond to the area where these two volcanoes overlap (Fig. 1).

Four different successive intrusion episodes have been distinguished in the BC (Stillman et al., 1975; Fúster et al., 1980, 1984a, b; Le Bas et al., 1986; Stillman, 1987), each of which produced contact metamorphism in the earlier rocks (Muñoz and Sagredo, 1974, 1989; Stillman et al., 1975; Stillman, 1987). All of them belong to the Central Basal Complex, and for this reason are given the name here Central plutonic groups 1, 2, 3 and 4 (CPG 1, 2, 3 and 4).

The age of the plutonic groups is not clearly defined, due mainly to the successive metamorphic processes undergone by the rocks (Cantagrel et al., 1993). The most homogeneous ages, and even here there is a certain degree of dispersion, correspond to the Vega del Río Palmas Ring Complex (part of CPG4). The age data (18.7 and 21.4 Ma) coincide with the latest activity in the CVC-II. The trachytic dykes might also have been part of that felsic activity. The Betancuria Trachytic-syenitic Complex, also a part of CPG4, is made up of subaerial rocks (Barrera et al., 1981) and, according to the ages given by Cantagrel et al. (1993), is contemporaneous with the latest activity in the CVC (Table 6).

The dating of the remaining plutonic groups is more confusing. Cantagrel et al. (1993) calculate an age of $25 \mathrm{Ma}$ for CPGl carbonatites, whereas Le Bas et al. (1986) and Stillman (1987) consider CPGl as well as CPG2 to be $>48 \mathrm{Ma}$.

There are some data other than radiometric ages that can help us establish a reasonable correlation between volcanic complexes and plutonic groups. For example, radial dyke systems such as those described in the CVC converge in the $\mathrm{BC}$ area where plutonic rocks are located and, therefore, where max- imum dyke intensity should be expected. In that case, CPG4, a group where dykes are very scarce or even absent, must neccessarily be younger than the CVC-I and the CVC-II, since both are extensively crossed by dykes. K-Ar ages estimated for CPG 4 (Table 6) are in agreement with this observation.

Javoy et al. (1986) have shown that metamorphism affecting CPG1 and CPG2 dykes and plutons took place in a water-rich environment not sited inside the ocean floor but rather under a very large volcanic island similar in height ( $4000 \mathrm{~m}$ or more) to the present Teide on Tenerife. Such an edifice must have been the CVC at a stage represented by the CVC-I and the CVC-II.

On the basis of age data (Feraud et al., 1985) and dykes intensity, it seems more reasonable to establish a parallelism between the CVC-II and CPG3. If so, CPG2 could be correlated with the CVC-I and CPG1 with an earlier submarine growth stage (Table 6).

Barrera et al. (1981), meanwhile, have recognized two different intrusion episodes on the northern BC exposures (Northern Plutonic Group, denoted NPG in this paper) which we consider to be independent of CPG1-4. The earlier NPG1 produced contact metamorphism in the submarine volcanoes and the later episode, NPG2, in all earlier rocks. Two radiometric ages have been advanced for NPG1: $25 \mathrm{Ma}$ (Le Bas et al., 1986) and 23.2 Ma (Cantagrel et al., 1993; U-Pb zircon). Correlation is even more difficult in this volcanic complex, although one hypothesis would be to correlate NPG2 with the Middle NVC-I and NPG1 with the Lower NVC-I (Table 6).

\section{Conclusions}

Fuerteventura is the result of several volcanic complexes built up along two main regional tectonic lineations. South of the island two more submarine edifices of possibly similar characteristics can be recognized. On Lanzarote, two other volcanic complexes and their submarine extension further north are also found. They all form a row of volcanoes along a lineation subparallel to the African coastline that may relate to early Atlantic spreading trends in this area.

Each volcanic complex was built by the piling up of several separate constructive episodes and this 
makes it possible to distinguish successive cycles of activity separated by tectonic phases. Due to proximity, correlation must exist between these tectonic phases and those in the neighbouring Atlas range, and hence the origin of the Fastern Canary Islands is linked to the tectonic evolution of the African Continent, as proposed by some authors (i.e., Anguita and Hernán, 1975; Robertson and Stillman, 1979a, b).

The $\mathrm{BC}$ should be reinterpreted as a rock complex comprising sediments which are previous to and contemporaneous with the growth of the island, volcanics representing the submarine stage of Fuerteventura and hypabyssal roots (dykes and plutons) from both the submarine stage and the later subaerial stage. In sum, the BC is not an earlier substratum for the subaerial series, but rather the $\mathrm{BC}$ and OBS constitute an inseparable whole within each major volcanic complex. The history of each volcanic complex, featuring one or more submarine and subaerial phases, includes volcanics (submarine and subaerial lavas) and their hypabyssal equivalents (plutons and dykes), showing different relationships between them.

\section{Acknowledgements}

This work was supported by the Spanish DGICYT Project PB 91-0147. Constructive comments by two anonymous reviewers and Prof. L. Wilson are gratefully acknowledged.

\section{References}

Abdel Monem, A., Watkins, N.D. and Gast, P.W., 1971. Potassium-argon ages, volcanic stratigraphy, and geomagnetic polarity history of the Canary Islands: Lanzarote, Fuerteventura, Gran Canaria and La Gomera. Am. J. Sci., 271: 490-521.

Ancochea, E., Cubas, C.R., Hernán, F. and Brändle, J.L., 1991. Edificios volcánicos en la Serie I de Fuerteventura: rasgos generales del Edificio Central. Geogaceta, 9: 60-62.

Ancochea, E., Brändle, J.L., Cubas, C.R., Hernán, F. and Huertas, M.J., 1993. La Serie I de la isla de Fuerteventura. Mem. R. Acad. Cienc. Exac. Fís. Nat. Madrid 27, 151 pp.

Anguita, F. and Hernán, F., 1975. A propagating fracture model versus a hot spot origin for the Canary Islands. Earth Planet. Sci. Lett., 27: 11-19.

Balcells, R., Barrera, J.L., Gómez, J.A., Cueto, L.A., Ancochea, E., Huertas, M.J., Ibarrola, E. and Snelling, N., 1994. Edades radiométricas de los edificios miocenos de Fuerteventura., Islas Canarias. Bol. Geol. Min. Esp., 105: 50-56.
Barrera, J.L., Fernández Santín, S., Fúster, J.M. and Ibarrola, E., 1981. Ijolitas-Sienitas - Carbonatitas de los macizos del norte del Complejo Basal de Fuerteventura, Islas Canarias. Bol. Geol. Min. Esp., 92-94: 309-321.

Bourcart, J. and Jeremine, E., 1938. Fuerteventura. Bull. Volcanol., II(4): $51-109$.

Brändle, J.L., Ancochea, E., Cubas, C.R. and Hernán, F., 1991. Análisis de enjambres de diques radiales utilizando un método matemático. Geogaceta, 10:97-100

Bravo, T., 1964. Geología General de las Islas Canarias. Goya, Santa Cruz de Tenerife, Vol. II, 592 pp.

Cantagrel, J.M., Fúster, J.M., Pin, C., Renaud, U. and Ibarrola, E., 1993. Age Miocène inférieur des carbonatites de Fuerteventura, $23 \mathrm{Ma}$ : U. $\mathrm{Pb}$ zircon et le magmatisme précoce d'une île océanique, îles Canaries. C. R. Acad. Sci. Paris, 316: 11471153

Casillas, R., Ahijado, A. and Hemández-Pacheco, A., 1994. Zonas de cizalla dúctil en el Complejo Basal de Fuerteventura. Geogaceta, 15: 117-121.

Cendrero, A., 1970. The volcano-plutonic complex of La Gomera, Canary Inslands. Bull. Volcanol., 34: 537-561.

Coello, J., Cantagrel, J.M., Ibarrola. E., Jamond. C.. Hernán, F., Fúster, J.M., Ancochea, E., Casquet, C., Diaz de Terán, J.R. and Cendrero, A., 1992. Evolution of the Eastem Volcanic Ridge of the Canary Islands based on new K-Ar data. J. Volcanol. Geotherm. Res., 53: 251-274

Cubas, C.R., Fernández Santín, S., Hemán, F., Hernández Pacheco, A. and De La Nuez, J., 1988. Los domos sálicos de Fuerteventura. Rev. Mat. Proc., 6: 71-97.

Cubas, C.R., Hemán, F., Ancochea, E. and Brändle, J.L., 1992. El Edificio Sur, Jandía de la Serie I de Fuerteventura: rasgos generales. Geogaceta, 11: 79-81.

Dañobeitia, J.J., 1988. Reconocimiento geofísico de estructuras submarinas situadas al norte y sur del archipiélago Canario. Rev. Soc. Geol. Esp., 1: 143-155.

Dañobeitia, J.J. and Collette, B.J., 1989. Estudio mediante sísmica de reflexión de un grupo de estructuras submarinas situadas al Norte y Sur del archipiélago Canario. Acta Geol. Hisp., 24: $147-163$.

Esnaola, J.M., 1984. Mapa geológico de España 1:25.000. Hoja 1.106-II-1.107-III, Antigua. Inst. Geol. Min. Esp., 23 pp.

Feraud, G., 1981. Datation de réseaux de dykes et de roches volcaniques sousmarines par les méthodes $\mathrm{K}-\mathrm{Ar}$ et ${ }^{40} \mathrm{Ar}-{ }^{39} \mathrm{Ar}$. Utilisation des dykes comme marqueurs de paléocontraites. Thesis, Univ. Nice, 146 pp.

Feraud, G., Giannerini, G., Campredon, R. and Stillman, C.J., 1985. Geochronology of some canarian dike swarms: contribution to the volcano-tectonic evolution of the archipielago. J. Volcanol. Geotherm. Res., 25: 29-52.

Fúster, J.M. and Aguilar, M., 1965. Nota previa sobre la geología del macizo de Betancuria. Fuerteventura, Islas Canarias. Estud. Geol., 21: 181-197.

Fúster, J.M., Cendrero, A., Gastesi, P., Ibarrola, E. and López Ruiz, J., 1968a. Geology and volcanology of Canary Islands, Fuerteventura. Inst. Lucas Mallada, C.S.I.C., Madrid, 243 pp.

Fúster, J.M., Femández Santín, S. and Sagredo, J., 1968b. Geología y Volcanología de las Islas Canarias. Lanzarote. Inst. Lucas Mallada, C.S.I.C., Madrid, 177 pp. 
Fúster, J.M., Muñoz, M., Sagredo, J., Yébenes, A., Bravo, T. and Hemández Pacheco, A., 1980. Excursión $121 \mathrm{~A}+\mathrm{C}$ del $26^{\circ}$ I.G.C. a las Islas Canarias. Bol. Geol. Min. Esp., XCI-II: $351-390$.

Fúster, J.M., Yébenes, A., Barrera, J.L., Muñoz, M. and Sagredo, J., 1984a. Mapa geológico de España 1:25.000. Hoja 1.106-IV, Betancuria. Inst. Geol. Min. Esp. 34 pp.

Fúster, J.M., Barrera, J.L., Muñoz, M., Sagredo, J. and Yébenes, A., 1984b. Mapa geologico de España 1:25.000. Hoja 1.106-III, Pájara. Inst. Geol. Min. Esp., 63 pp.

Gastesi, P., 1973. Is the Betancuria Massif, Fuerteventura, Canary Islands, an uplifted piece of oceanic crust? Nat. Phys. Sci., 246: 102-104.

Grunau, H., Lehner, R., Cleintuar, P., Allenbach, M.R. and Baker, G., 1975. New radiometric ages and seismic data from Fuerteventura, Canary Islands, Maio, Cape Verde Islands and Sao Tomé, Gulf of Guinea. (Progress in Geodynamics.) R. Soc. Neth. Acad. Art Sci, pp. 90-108.

Hartung, G., 1857. Die geologischen Verhältnisse der Inseln Lanzarote und Fuerteventura. Neue Denkschr. Alg. Schweiz. Ges. Gesammt. Naturwiss. 15, 163 pp.

Hausen, H., 1958. On the geology of Fuerteventura, Canary Islands. Soc. Sci. Fenn. Comm. Phys. Math. 22(1), 211 pp.

Hernán, F., Ancochea, E., Brändle, J.L. and Cubas, C.R., 1993. Características generales en el Edificio Norte de la Serie 1 de Fuerteventura. Geogaceta, 13: 62-64

Hernández Pacheco, A., 1973. Sobre el significado de las rocas granudas gabroides de los complejos basales de las islas de Fuerteventura, La Palma y La Gomera, Archipiélago Canario. Estud. Geol., 29: 549-557.

Ibarrola, E., Cantagrel, J.M., Fúster, J.M., Coello, J. and Jamond, C., 1988. Geocronología de las Series volcánicas neógenas de Lanzarote, Islas Canarias. Il Congr. Geol. España, pp. 345-348

Ibarrola, E., Fúster, J.M. and Cantagrel, J.M., 1989. Edades K-Ar de las rocas volcánicas submarinas en el sector norte del Complejo Basal de Fuerteventura. E.S.F. Meet. Canarian Volcanism, pp. 124-129.

Javoy, M., Stillman, C.J. and Pineau, F., 1986. Oxygen and hydrogen isotope studies on the basal complexes of the Canary Islands: implications on the conditions of their genesis. Contrib. Mineral Petrol., 92: 225-235.

Le Bas, M.J., 1981. The pyroxenite-ijolite-carbonatite intrusive igneous complexes of Fuerteventura, Canary Islands. J. Geol. Soc. London, 138: 496.

Le Bas, M.J., Rex, D.C. and Stillman, C.J., 1986. The early magmatic chronology of Fuerteventura, Canary Islands. Geol. Mag., 123: 287-298.

Le Maitre, R.W., 1976. Some problems of the projection of chemical data into mineralogical classifications. Contrib. Mineral. Petrol,, 56: 181-189.

López Ruiz, J., 1970. Estudio petrográfico y geoquímico del complejo filoniano de Fuerteventura, Islas Canarias. Estud. Geol., 26: 173-208.

Luyendyk, B. and Bunce, E.T., 1973. Geophysical study of the northwest African Margin of Morocco. Deep Sea Res., 20: 537-549.

Macdonald, G.A. and Katsura, J., 1964. Chemical composition of Hawaiian lavas. J. Petrol., 5: 82-133.
Martín, M., 1984. Mapa geológico de España 1:25.000. Hoja 1.106-I-1.107-IV, Puerto del Rosario. Inst. Geol. Min. Esp., $18 \mathrm{pp}$.

Muñoz, M., 1969. Estudio petrológico de las formaciones alcalinas de Fuerteventura., Islas Canarias. Estud. Geol., 25: $257-$ 310.

Muñoz, M. and Sagredo, J., 1974. Existencia de metamorfismos superpuestos en el complejo basal de Fuerteventura, Canarias. I Asam. Nac. Geod. Geofis., p. 1287 (abstract).

Muñoz, M. and Sagredo, J., 1989. Características del metamorfismo térmico producido por los eventos plutónicos intrusivos más recientes del complejo basal de Fuerteventura. E.S.F. Meet. Canarian Volcanism, pp. 104-108.

Peterson, D.W. and Moore, R.B., 1987. Geologic history and evolution of geologic concepts, island of Hawaii. In: R.W. Decker, T.L. Wright and P.H. Stauffer (Editors), Volcanism in Hawaii. U.S. Geol. Surv., Prof. Pap., 1350: 149-189.

Robertson, A.H.F. and Bernoulli, D., 1982. Stratigraphy, facies and significance of late Mesozoic and early Tertiary sedimentary rocks of Fuerteventura, Canary Islands and Maio, Cape Verde Islands. In: U. von Rad, K. Hinz, M. Sarnthein and E. Seibold (Editors), Geology of the Northwest African Continental Margin. Springer-Verlag, Berlin, pp. 498-525.

Robertson, A.H.F. and Stillman, C.J., 1979a. Late sedimentary rocks of Fuerteventura, Canary Islands. Implications for West African continental margin evolution. J. Geol. Soc. London, 136: $47-60$.

Robertson, A.H.F. and Stillman, C.J., 1979b. Submarine volcanic and associated sedimentary rocks of the Fuerteventura Basal Complex, Canary Islands. Geol. Mag., 116: 203-214.

Rona, P.A. and Nalwalk, A.J., 1970. Post-early Pliocene unconformity on Fuerteventura, Canary Islands. Geol. Soc. Am. Bull., 81: 2117-2122.

Rothe, P., 1966. Zum Alter des Volkanismus auf dem östlichen Kanaren. Soc. Sci. Fenn. Comm. Phys. Math., 31: 1-80.

Rothe, P., 1968. Mesozoische Flysch-Ablagerungen auf Kanarieninsel Fuerteventura. Geol. Rundsch., 58: 314-322

Schmincke, H.U. and Von Rad, U., 1979. Neogene evolution of Canary Island volcanism inferred from ash layers and volcaniclastic sandstones of DSDP site 397, Leg 47 A. Init. Rep. DSDP, 47: 703-725.

Steiger, R.H. and Jaeger, E., 1977. Subcommision of geochronology: of the use of decay constants in geo and cosmochronology. Earth Planet. Sci. Lett., 36: 359-362.

Stillman, C.J., 1987. A Canary Islands dyke swarm: Implications for the formation of oceanic islands by extensional fissural volcanism. In: H.C. Halls and W.F. Fahrig (Editors), Mafic Dyke Swarms. Geol. Assoc. Can. Spec. Pap., 34: 243-255.

Stillman, C.J., Fúster, J.M., Bennell Baker, M.J., Muñoz, M., Smewing, J.D. and Sagredo, J., 1975. Basal complex of Fuerteventura is an oceanic intrusive complex with rift-system affinities. Nature, 257: 469-470.

Uchupi, E., Emery, K.O., Bowin, C.O and Phillips, J.D., 1976. Continental margin of Western Africa: Senegal to Portugal. Am. Assac. Pet. Geol. Bull., 60: 809-878.

Weigel, W., Goldflam, P. and Hinz, K., 1978. The crustal structure of the Conception Bank. Mar. Geophys. Res., 3: 381-392. 